\title{
Adenosine and Dopamine Receptors Coregulate Photoreceptor Coupling via Gap Junction Phosphorylation in Mouse Retina
}

\author{
Hongyan Li, ${ }^{1}$ Zhijing Zhang, ${ }^{1}$ Michael R. Blackburn, ${ }^{2,3}$ Steven W. Wang, ${ }^{1,3}$ Christophe P. Ribelayga, ${ }^{1,3}$ \\ and John $0^{\prime}$ Brien $^{1,3}$ \\ ${ }^{1}$ Richard S. Ruiz, MD, Department of Ophthalmology and Visual Science, The University of Texas Medical School and ${ }^{2}$ Department of Biochemistry and \\ Molecular Biology, The University of Texas Medical School, Houston, Texas 77030; and ${ }^{3}$ Graduate School of Biomedical Sciences, The University of Texas \\ Health Science Center at Houston, Houston, Texas 77030
}

Gap junctions in retinal photoreceptors suppress voltage noise and facilitate input of rod signals into the cone pathway during mesopic vision. These synapses are highly plastic and regulated by light and circadian clocks. Recent studies have revealed an important role for connexin36 (Cx36) phosphorylation by protein kinase A (PKA) in regulating cell-cell coupling. Dopamine is a light-adaptive signal in the retina, causing uncoupling of photoreceptors via D4 receptors (D4R), which inhibit adenylyl cyclase (AC) and reduce PKA activity. We hypothesized that adenosine, with its extracellular levels increasing in darkness, may serve as a dark signal to coregulate photoreceptor coupling through modulation of gap junction phosphorylation. Both D4R and A2a receptor (A2aR) mRNAs were present in photoreceptors, inner nuclear layer neurons, and ganglion cells in C57BL/6 mouse retina, and showed cyclic expression with partially overlapping rhythms. Pharmacologically activating A2aR or inhibiting D4R in light-adapted daytime retina increased photoreceptor coupling. Cx36 among photoreceptor terminals, representing predominantly rod-cone gap junctions but possibly including some rod-rod and conecone gap junctions, was phosphorylated in a PKA-dependent manner by the same treatments. Conversely, inhibiting A2aR or activating D4R in daytime dark-adapted retina decreased $\mathrm{Cx} 36$ phosphorylation with similar PKA dependence. A2a-deficient mouse retina showed defective regulation of photoreceptor gap junction phosphorylation, fairly regular dopamine release, and moderately downregulated expression of D4R and AC type $1 \mathrm{mRNA}$. We conclude that adenosine and dopamine coregulate photoreceptor coupling through opposite action on the PKA pathway and Cx36 phosphorylation. In addition, loss of the A2aR hampered D4R gene expression and function.

\section{Introduction}

Gap junctions are fundamental elements of neuronal wiring in the retina (Bloomfield and Völgyi, 2009). Photoreceptor gap junctions have critical functions in visual information processing. Cell-cell coupling improves the signal/noise ratio over much of the photoreceptor operating range (Lamb and Simon, 1976) and may improve contrast detection and detection of small stimuli (Lebedev et al., 1998; Li et al., 2012). Rod-cone coupling allows pathway convergence (Nelson, 1977; Schneeweis and Schnapf, 1995; Trümpler et al., 2008), forming a medium-

Received June 12, 2012; revised Dec. 20, 2012; accepted Dec. 24, 2012.

Author contributions: H.L., S.W.W., C.P.R., and J.O. designed research; H.L. and Z.Z. performed research; M.R.B., S.W.W., and C.P.R. contributed unpublished reagents/analytic tools; H.L., C.P.R., and J.0. analyzed data; H.L. and J.O. wrote the paper.

This work was supported by the National Institutes of Health Grants EY012857 (J.0.), EY018640 (C.P.R.), EY018352 (S.W.W.), HL070952 (M.R.B.), and core grant EY010608. We thank Dr. Jaroslaw Aronowski and Dr. Xiurong Zhao for assistance with real-time PCR, Dr. Roger Janz for donating the antibody against syntaxin3, Jose G. Molina and Ya-Ping Lin for help with animal maintenance and breeding, Dr. Stephen C. Massey for help with confocal microscopy, and Dr. Carmen W. Dessauer for helpful discussion on this study.

The authors declare no competing financial interests.

Correspondence should be addressed to Dr. John 0'Brien, Department of Ophthalmology and Visual Science, The University of Texas Health Science Center at Houston, 6431 Fannin Street, MSB 7.024, Houston, TX 77030. E-mail: John.0Brien@uth.tmc.edu.

DOI:10.1523/JNEUROSCI.2807-12.2013

Copyright $\odot 2013$ the authors $\quad 0270-6474 / 13 / 333135-16 \$ 15.00 / 0$ sensitivity pathway that functions during mesopic vision when the rod pathway becomes saturated (DeVries and Baylor, 1995).

Photoreceptor coupling depends on a circadian rhythm and light/dark adaptation. It is maximal at night in dark-adapted conditions and minimal under light-adapted conditions (Wang and Mangel, 1996; Ribelayga et al., 2008). Changes in photoreceptor coupling are driven by gap junction phosphorylation and dependent on protein kinase A (PKA) activity (Li et al., 2009). There is a direct correlation between connexin35 (Cx35) (the fish homolog of mammalian Cx36) phosphorylation and photoreceptor coupling such that both are high in darkness at night, and low under daytime illumination ( $\mathrm{Li}$ and O'Brien, 2012; Li et al., 2009).

The catecholamine dopamine is released from dopaminergic amacrine cells. Dopamine displays light-adaptive effects, acting both as a neurotransmitter and a neurohormone on a variety of retinal neurons (Pierce and Besharse, 1985; Weiler et al., 1988; Dearry and Burnside, 1989). Dopamine synthesis and release are stimulated by light, and in some species, controlled by a circadian clock so that dopamine release is highest during the daytime in light and lowest at night in darkness (Kramer, 1971; Iuvone et al., 1978; Nir et al., 2000; Doyle et al., 2002b; Ribelayga et al., 2004). In photoreceptors, activation of dopamine D4 receptors (D4R) 
suppresses the light-sensitive pool of cAMP (Cohen and Blazynski, 1990; Cohen et al., 1992), reduces PKA activity, and downregulates type 1 adenylyl cyclase (AC1) expression (Jackson et al., 2009). A circadian rhythm of extracellular adenosine in the retina has the opposite phase as does dopamine, displaying an increased level in darkness and at night compared with illumination (Ribelayga and Mangel, 2005). Adenosine regulates a largely overlapping suite of photoreceptor functions in the opposite manner as does dopamine (Rey and Burnside, 1999; Stella et al., 2002, 2003). Activation of A2a receptors (A2aR), which are expressed on photoreceptors (Blazynski, 1990; Kvanta et al., 1997), stimulates intracellular AC and thus increases cAMP level (Londos et al., 1980; Friedman et al., 1989).

In the current study we examined the hypothesis that D4R and A2aR may coregulate photoreceptor coupling through antagonizing actions on gap junction phosphorylation using C57BL/6 mice. In this animal model, melatonin synthesis is constitutively low due to a natural mutation in the arylalkylamine $\mathrm{N}$-acetyltransferase gene (Roseboom et al., 1998), and thus dopamine release is mainly controlled by light (Doyle et al., 2002a). We found that $\mathrm{A} 2 \mathrm{aR}$ played a dark-adaptive role in regulating photoreceptor coupling. The regulation is primarily direct through the control of PKA activity in the photoreceptor, but may also be partially indirect, through the modulation of D4R gene expression.

\section{Materials and Methods}

Animals. The wild-type (WT) mice used in the current study were C57BL/6 from The Jackson Laboratory (stock\# 000664). The A2aRdeficient mice have a hybrid genetic background of 129-Steel and C57BL/6 (Chen et al., 1999). All mice used in this study were 1.5-4 months old. Within the same types of experiment, mice at matched ages were chosen to avoid the possible variability in gap junction physiology caused by aging (Fujisawa et al., 1976; Hansen et al., 2005). Animals of both sexes were used. Animals were maintained on a daily $12 \mathrm{~h} \mathrm{light/dark}$ (L/D) cycle. Zeitgeber time 0 (ZT0) is defined as time of lights on (7:00 A.M.); while ZT12 is defined as time of lights off (7:00 P.M.). Procedures were approved by the Animal Welfare Committee at the University of Texas Health Science Center at Houston.

Materials. Reagents were purchased from the following sources: Ames' medium w/L-glutamine was from US Biological. The D4R agonist PD168077 maleate (PD) and antagonist L-745870 trihydrochloride, the A2aR agonist CGS21680 hydrochloride (CGS) and antagonist 8-(3Chlorostyryl) caffeine (CSC) were purchased from Tocris Bioscience. cAMP analogs, PKA activator Sp-8-CPT-cAMPS (Sp), and PKA inhibitor Rp-8-CPT-cAMPS (Rp) were from Axxora. In studies using PD, CGS or CSC, $0.1 \%$ dimethylsulfoxide (DMSO; Sigma-Aldrich) was used to increase the solubility of drugs. The corresponding control used $0.1 \%$ DMSO as well.

Tracer coupling measurements. We estimated gap junction coupling between photoreceptors by measuring tracer diffusion of Neurobiotin (Vector Laboratories) using the cut loading technique as described in detail previously (Ribelayga et al., 2008; Li et al., 2009; Choi et al., 2012). In brief, mice were killed by cervical dislocation and eyes were quickly dissected in oxygenated Ames' medium (supplemented with $12 \mathrm{~mm}$ $\mathrm{NaHCO}_{3}, \mathrm{pH} 7.4$ ) at $37^{\circ} \mathrm{C}$, and the retinas were flat mounted onto nitrocellulose filter paper (EMD Millipore). The flat-mount retina was incubated in Ames' for $45 \mathrm{~min}$, followed by an additional $20 \mathrm{~min}$ with or without drugs at $37^{\circ} \mathrm{C}$. Then the retina was cut with a dewaxed feather blade that had been dipped in $5 \%$ Neurobiotin with or without $2 \%$ lysine fixable dextran conjugated to fluorescein (10,000 MW; Life Technologies). Retina pieces were incubated with Ames' medium with or without drugs for $15 \mathrm{~min}$ at $37^{\circ} \mathrm{C}$ and subsequently fixed with $4 \%$ paraformaldehyde (PFA) in $0.1 \mathrm{~m}$ phosphate buffer, $\mathrm{pH} 7.5(\mathrm{~PB})$ overnight at $4^{\circ} \mathrm{C}$. All experiments involving dark-adapted retina were conducted in darkness or under infrared light. During all steps before fixation was completed, lighting conditions remained the same.

Fixed, washed retina tissue was labeled with $0.75 \mu \mathrm{g} / \mathrm{ml}$ Cy3conjugated streptavidin (Jackson ImmunoResearch) at $4^{\circ} \mathrm{C}$ overnight or together with $25 \mu \mathrm{g} / \mathrm{ml}$ fluorescein-labeled peanut agglutinin (PNA; Vector Laboratories) for $3 \mathrm{~d}$. Retina tissue was flat mounted on slides with Vectashield mounting medium (Vector Laboratories). Cut loading fills cells nonselectively throughout the retina along the slice plane. To study photoreceptor coupling, digital images at the level of photoreceptor inner segments were taken using a Zeiss LSM 510 Meta confocal microscope. Similar settings of pinhole, contrast, and brightness parameters were used for all experimental conditions. Projections of two adjacent confocal images comprising $0.9 \mu \mathrm{m}$ focal depth were used for analysis. Under each condition, samples were collected from three to five different animals from least two separate experiments.

Images were analyzed using SimplePCI (Hamamatsu Photonics) and MATLAB (MathWorks) software as previously described (Li et al., 2009). Intensity of Neurobiotin-positive signal was measured in $0.3 \mu \mathrm{m}$ diameter circles centered on photoreceptor inner segments. Cell-cell spacings were estimated based upon an average of at least 10 measurements. We estimated tracer diffusion using a linear compartmental diffusion model (Zimmerman and Rose, 1985) as applied to neural networks in retina (Mills and Massey, 1998; O'Brien et al., 2004). This model assumes that the photoreceptor array behaves as a linear chain of compartments connected by identical gap junctions characterized by a rate-limiting diffusion coefficient $(k)$. Since the model is linear and presumes that loading occurs in a single compartment, we analyzed narrow clusters of cells extending perpendicular to the cut edge. Means of diffusion coefficients from several different clusters in a pair of retinas were used to represent one animal.

In vitro eyecup incubations. To use pharmacological interventions to study signaling pathways that control phosphorylation of $\mathrm{Cx} 36$, we used an in vitro eyecup preparation. Mice were killed and the eyes collected. Eyecups were quickly prepared by removing the anterior segment and lens and then incubated in oxygenated Ames' medium at $37^{\circ} \mathrm{C}$. After 45 min resting, the culture medium was changed into fresh Ames' and eyecups were incubated for another $20 \mathrm{~min}$ with or without drugs, if applicable. The eyecup was immediately fixed with $1.5 \% \mathrm{~N}$-(3-dimethylaminopropyl)- $\mathrm{N}^{\prime}$-ethylcarbodiimide hydrochloride ("carbodiimide"; Sigma-Aldrich) in $0.1 \mathrm{M} \mathrm{PB,} \mathrm{pH} \mathrm{7.5,} \mathrm{for} 30$ min at room temperature and cryoprotected in $30 \%$ sucrose at $4^{\circ} \mathrm{C}$.

In preliminary studies, we compared the phosphorylation levels of Cx36 in the outer plexiform layer (OPL; the synaptic layer containing photoreceptor synapses) in acutely isolated eyes at various states of dark adaptation to those from in vitro eyecup preparations treated as described above. In the acute group, mice were killed and eyes were quickly collected in ice-cold PBS. A small puncture was made in the center of the cornea with a sharp needle for easy access of fixative. The eyes were then immediately fixed with $1.5 \%$ carbodiimide in $0.1 \mathrm{M} \mathrm{PB}$ for $30 \mathrm{~min}$ at room temperature. Sectioning and immunocytochemistry (see below) were performed in the same manner for both groups. Results with daytime light-adapted and 2, 4, and $6 \mathrm{~h}$ dark-adapted retina showed no difference between the two methods in the phosphorylation levels (twoway ANOVA: methods, $p=0.71$; lighting, $p=0.01 ; n=3 /$ condition), supporting the contention that data from the excised eyecup preparation are representative of processes occurring in the intact eye.

Immunocytochemistry, image acquisition, and phosphorylation level estimation. For immunofluorescence localization of Cx36 in the photoreceptor layer, mouse eyes were dissected in PBS and lenses were removed. The eyecup was fixed at room temperature with $2 \%$ carbodiimide in 0.1 M PB for $40 \mathrm{~min}$ followed by $2 \%$ PFA in $0.1 \mathrm{M} \mathrm{PB}$ for another $10 \mathrm{~min}$. Fixed tissue was cryoprotected in $30 \%$ sucrose overnight at $4^{\circ} \mathrm{C}$, and embedded in OCT. Tissue was sectioned into $16 \mu \mathrm{m}$ slices using a cryostat and blocked with $10 \%$ donkey serum (Jackson ImmunoResearch) in PBS with $0.1 \%$ Triton X-100 (PBST) at room temperature for $30 \mathrm{~min}$. Sections were incubated with a variety of antibodies in PBST overnight at room temperature. Antibodies used included rabbit anti-syntaxin3 (1/ 100; gift from Dr. Roger Janz), mouse $\mathrm{IgG}_{1}$ anti-Cx36 (mCx36; $10 \mu \mathrm{g} / \mathrm{ml}$, EMD Millipore; MAB3045), goat anti-arrestin ( $2 \mu \mathrm{g} / \mathrm{ml}$; Santa Cruz Biotechnology), mouse $\operatorname{IgG}_{2 \mathrm{a}}$ anti-PSD-95 clone K28/43 (1/100; University 
Table 1. Primers for real-time PCR study

\begin{tabular}{lll}
\hline Name & Primer sequence & References \\
\hline 185 rRNA-forward & TAGAGTGTTCAAAGCAGGCCCGA & Jackson et al., 2009 \\
185 rRNA-reverse & ATGCTTTCGCTCTGGTCGTCTT & Streitová et al., 2010 \\
A2aR-forward & CCGAATTCCACTCCGGTACA & Designed using http://frodo.wi.mit.edu/primer3/ \\
A2aR-reverse & CAGTTGTTCCAGCCCAGCAT & \\
D4R-forward & TGCCCTCAACCCATCATCTACAC & Jackson et al., 2009 \\
D4R-reverse & CAACCCCAGCCTTCATAAGTGGT & \\
AC1-forward & CACAGCAGGACCAAGGCTAAGAA & \\
AC1-reverse & TGCCAACTCGGAGACAAAGTCGT & \\
\hline
\end{tabular}

of California Davis/National Institutes of Health NeuroMab Facility, Davis, CA). Following extensive washing with PBS, sections were incubated with suitable secondary antibodies including $3.75 \mu \mathrm{g} / \mathrm{ml}$ Alexa Fluor 647 donkey anti-rabbit (Jackson ImmunoResearch; for sytaxin3), $5 \mu \mathrm{g} / \mathrm{ml}$ Alexa Fluor 555 goat anti-mouse $\operatorname{IgG}_{1}$ (Life Technologies; recognizing Cx36 while colabeling with mouse $\operatorname{IgG}_{2 \mathrm{a}}$ PSD-95), or $3.5 \mu \mathrm{g} / \mathrm{ml}$ Cy3 donkey anti-mouse IgG (Jackson ImmunoResearch; for Cx36), $5 \mu \mathrm{g} / \mathrm{ml}$ Alexa Fluor 488 donkey anti-goat IgG (Life Technologies; for arrestin), and $5 \mu \mathrm{g} / \mathrm{ml}$ Alexa Fluor 488 goat anti-mouse $\operatorname{IgG}_{2 \mathrm{a}}$ (Life Technologies; for PSD-95). The secondary antibodies were incubated at room temperature for $3 \mathrm{~h}$. Nuclei were counterstained by mounting sections with Vectashield mounting medium with DAPI (Vector Laboratories).

The phosphorylation state of Cx36 gap junctions was measured by immunocytochemistry as described previously (Kothmann et al., 2007, 2009; Li et al., 2009). Briefly, cryostat sections of eyecups fixed with $1.5 \%$ carbodiimide were rehydrated with PBST and blocked with 10\% donkey serum in PBST for $1 \mathrm{~h}$ at room temperature. The sections were probed at $4^{\circ} \mathrm{C}$ overnight with $\mathrm{mCx} 36$ at $2.5 \mu \mathrm{g} / \mathrm{ml}$ and rabbit anti-Cx36 phosphoSer293 (Kothmann et al., 2007) at $0.8 \mu \mathrm{g} / \mathrm{ml}$ in $10 \%$ donkey serum with PBST. The sections were then incubated with Cy3-conjugated donkey anti-mouse IgG $(2.1 \mu \mathrm{g} / \mathrm{ml}$; Jackson ImmunoResearch) and Alexa 488conjugated donkey anti-rabbit IgG $(2.0 \mu \mathrm{g} / \mathrm{ml}$; Life Technologies $)$ at room temperature for $2 \mathrm{~h}$. Sections were preserved in Vectashield mounting medium.

Image acquisition and data analysis were described previously (Kothmann et al., 2007, 2009; Li et al., 2009). In brief, 12-bit photomicrographs were taken using the confocal microscope with fixed laser power settings. The detector gain and offset parameters were adjusted so that the intensity of most pixels fell within the dynamic range of the detector and the intensity of the most brightly labeled conditions showed very limited saturation. For each experiment, once settings were optimized, they remained unchanged for all conditions and treatments to avoid imaging biases. Images were taken in the OPL randomly selected within the region from 50 to $80 \%$ of the distance from the optic nerve head to the periphery. Three neighboring scans at $0.3 \mu \mathrm{m}$ intervals were stacked to generate a $35 \times 16 \times 0.9 \mu \mathrm{m}$ volume, which was exported into one 12-bit tiff image. Five images were collected from two cryosections of one eyecup to represent one animal.

The confocal images were analyzed with Simple PCI software (Hamamatsu) as described previously (Li et al., 2009). In each image, regions of interest (ROI) were selected to circle mCx36 immunoreactive puncta by applying a $20 \%$ threshold. Ideally one ROI represented one gap junction plaque, although occasionally adjacent gap junctions were merged into a single ROI. The number of $\mathrm{Cx} 36$ plaques was estimated by counting the total number of ROI in each image. The average ROI count over five images was used to represent one animal. The phosphorylation level was estimated by taking a ratio of the intensity of phospho-S293 to that of $\mathrm{mCx} 36$ labeling within each ROI. Since the population of phosphorylation state ratios is not normally distributed, the median was calculated from all $\mathrm{Cx} 36$ plaques in five images to represent the phosphorylation level of one animal (Li et al., 2009).

In situ hybridization. To localize the $\mathrm{A} 2 \mathrm{aR}$ and $\mathrm{D} 4 \mathrm{R}$ in the mouse retina, we performed in situ hybridization (ISH) for each gene. A probe for the D4R was designed based upon NCBI reference sequence NM 007878.2. To make D4R RNA probes, a 281 bp DNA template was amplified by PCR using a cDNA clone (Cat\# MMM1013-99622152;
Thermo Fisher Scientific) as template and the following primer set: forward ACCCTACTCAGGGTCCCTTC, reverse GATGTGCACCACGAAGAAAG. Probes for A2aR were designed based upon NCBI reference sequence NM 009630.2. The DNA template for generating RNA probes was a 32 mer oligonucleotide (Life Technologies). The antisense sequence is as follows: ATCATCAACTGCTTCACCTTCTTCTGCTCCAC. T7 or SP6 RNA polymerase promoters were incorporated into the oligos, and digoxigenin (DIG)-labeled RNA probes were synthesized by in vitro transcription (Life Technologies; MAXIscript kit) in the presence of DIG-dUTP (Roche) following the manufacturer's instructions.

We wanted to compare the transcript levels throughout an L/D cycle. To accomplish this, mouse eyes were collected at four different time points: ZT23.5 (dark), ZT5.5 (light), ZT11.5 (light), and ZT17.5 (dark). Eyes were quickly fixed with $4 \%$ PFA in $0.1 \mathrm{M} \mathrm{PB}$ for $48 \mathrm{~h}$ at $4^{\circ} \mathrm{C}$, and then embedded in paraffin and cut into $9 \mu \mathrm{m}$ sections using a microtome. Retina sections were dewaxed, treated with $30 \mu \mathrm{g} / \mathrm{ml}$ proteinase $\mathrm{K}$ (Roche) at $37^{\circ} \mathrm{C}$ for $20 \mathrm{~min}$, and postfixed in $4 \%$ PFA in $0.1 \mathrm{M} \mathrm{PB}$ for 20 min. To reduce nonspecific background, sections were incubated with $0.5 \%$ acetic anhydride in $0.1 \mathrm{~m}$ triethanolamine for $10 \mathrm{~min}$ twice, with rinsing in PBS between incubations. Hybridization was performed overnight with riboprobes for $\mathrm{A} 2 \mathrm{aR}$ at $48^{\circ} \mathrm{C}$ or for $\mathrm{D} 4 \mathrm{R}$ at $60^{\circ} \mathrm{C}$. Sections were then washed at hybridization temperature with buffers at high stringency: $50 \%$ formamide with $2 \times \mathrm{SSC}\left(300 \mathrm{~mm} \mathrm{NaCl}, 30 \mathrm{~mm} \mathrm{Na}_{3}\right.$ citrate, $\mathrm{pH}$ 7.0) for $30 \mathrm{~min}, 1 \times$ SSC for $30 \mathrm{~min}$, and $0.2 \times$ SSC for $30 \mathrm{~min}$. Nonhybridized RNA probes were deactivated by treatment of $0.2 \mu \mathrm{g} / \mathrm{ml}$ RNase A (Sigma-Aldrich) at $37^{\circ} \mathrm{C}$ for $30 \mathrm{~min}$. Hybridization signals were detected by incubating retina sections with $7.5 \mathrm{mU} / \mathrm{ml}$ antibody against DIG conjugated with horseradish peroxidase (Roche) at $4^{\circ} \mathrm{C}$ overnight. On the third day, color was developed with the TSA plus Cy3 system (PerkinElmer) for various time periods ranging from $30 \mathrm{~min}$ to $2 \mathrm{~h}$.

Some retina sections with ISH completed were subsequently immunostained. Sections were rinsed in PBST for $1 \mathrm{~h}$ and blocked with $10 \%$ donkey serum in PBST for $1 \mathrm{~h}$ at room temperature. Sections were incubated with 1/1000 sheep polyclonal antibody against tyrosine hydroxylase (EMD Millipore) overnight at room temperature. After rinsing with PBS, sections were incubated with $5 \mu \mathrm{g} / \mathrm{ml}$ Alexa Fluor 488 donkey antisheep IgG (Invitrogen) for $3 \mathrm{~h}$ at room temperature. Images were taken using a confocal microscope.

Real-time PCR. After mice were killed, eyes were quickly frozen with liquid nitrogen and stored at $-80^{\circ} \mathrm{C}$. Retinas were collected in ice-cold PBS and homogenized in TRI reagent (Sigma-Aldrich). For each animal, RNA was extracted from retinas of both eyes and treated with TURBO DNase (Life Technologies) following manufacturer's instructions. First strand cDNA was synthesized using SuperScript III Transcriptase (Life Technologies). Real-time PCR was performed using SYBR Green PCR master mix (Life Technologies) and the following program: $95^{\circ} \mathrm{C}$ for 2 min, 40 cycles of $95^{\circ} \mathrm{C}$ for $30 \mathrm{~s}, 57^{\circ} \mathrm{C}$ for $30 \mathrm{~s}$, and $72^{\circ} \mathrm{C}$ for $30 \mathrm{~s}$ in the Mastercycler EP Gradient PCR machine (Eppendorf). Each sample was assayed in duplicate. The threshold cycle $\left(\mathrm{C}_{\mathrm{T}}\right)$ of $\mathrm{A} 2 \mathrm{aR}, \mathrm{D} 4 \mathrm{R}$, and $\mathrm{AC1}$ gene amplification was normalized with the $\mathrm{C}_{\mathrm{T}}$ of $18 \mathrm{~S} \mathrm{rRNA}$, and relative to the $\mathrm{C}_{\mathrm{T}}$ of each gene at ZT5.5 in the WT mouse retina using the comparative $\mathrm{C}_{\mathrm{T}}$ method (Schmittgen and Livak, 2008). Information for primers is provided in Table 1.

HPLC. The concentrations of dopamine and its metabolite dihydroxyphenylacetic acid (DOPAC) were assayed in mouse retina by HPLC. 
Frozen mouse eyes were homogenized by sonication in the presence of $0.1 \mathrm{M}$ perchloric acid and $0.5 \mathrm{~mm}$ ascorbic acid. Homogenate was centrifuged at 15,000 rpm twice for a total of 50 min. The extract from one eye was assayed to represent one animal. Samples were resolved in a Shimadzu HPLC system (Shimadzu Scientific Instruments) using a C18 column (150 $\mathrm{mm} \times 4.6 \mathrm{~mm}, 5 \mu \mathrm{m}$ porous silica) with an isocratic mobile phase containing $50 \mathrm{~mm}$ $\mathrm{KH}_{2} \mathrm{PO}_{4}, 0.02 \%$ octyl sodium sulfate, $15 \%$ methanol, and $0.1 \mathrm{~mm} \mathrm{Na}_{2}$-EDTA, pH 3.1. Dopamine and DOPAC were detected by an amperometric detector (BASi) and normalized to a standard solution containing dopamine and DOPAC with known concentration in the same HPLC assay.

\section{Results}

Dark adaptation resembles the nighttime state in C57BL/6 mice

Photoreceptor gap junction coupling is controlled by a circadian rhythm of dopamine secretion and light conditions (Yang and Wu, 1989; Wang and Mangel, 1996; Krizaj et al., 1998; Ribelayga et al., 2008; Li et al., 2009). The dopamine rhythm is in turn controlled partially by a potent circadian rhythm in photoreceptor melatonin secretion (Dubocovich, 1983; Dubocovich and Takahashi, 1987; Nowak et al., 1992). In C57BL/6 mice, melatonin secretion is constitutively low due to a mutation in the gene for rate-limiting enzyme of the melatonin synthetic pathway, arylalkylamine $N$-acetyl transferase (Roseboom et al., 1998). In these animals, dopamine secretion is controlled by light conditions (Doyle et al., 2002a), suggesting that dark adaptation may recapitulate the nighttime state. To test this hypothesis, we compared photoreceptor coupling and dopamine secretion in darkness at night to that in dark-adapted conditions in the daytime.

As previously found in zebrafish (Li et al., 2009), daytime light-adapted mouse retina displayed weak tracer diffusion among photoreceptors, limited to loaded cells along the cut edge of the retina and occasionally another row of tracer coupled cells (Fig. 1A). In contrast, nighttime dark-adapted mouse retina showed extensive tracer diffusion beyond the loaded cells of the cut edge, indicating much more extensive coupling within the photoreceptor network (Fig. 1B). Dark adaptation for 2, 4, and $6 \mathrm{~h}$ in the daytime also increased tracer diffusion through the photoreceptor network (Fig. $1 C-E$ ). No sign of diffusion was observed in labeling of the lysine fixable dextran (10,000 MW), which was coapplied with Neurobiotin (data not shown). The majority of Neurobiotin-loaded cells were not colocalized with PNA (Fig. 1D), indicating that they are rods. The fraction of PNA-labeled cones within the Neurobiotin-loaded photorecep-
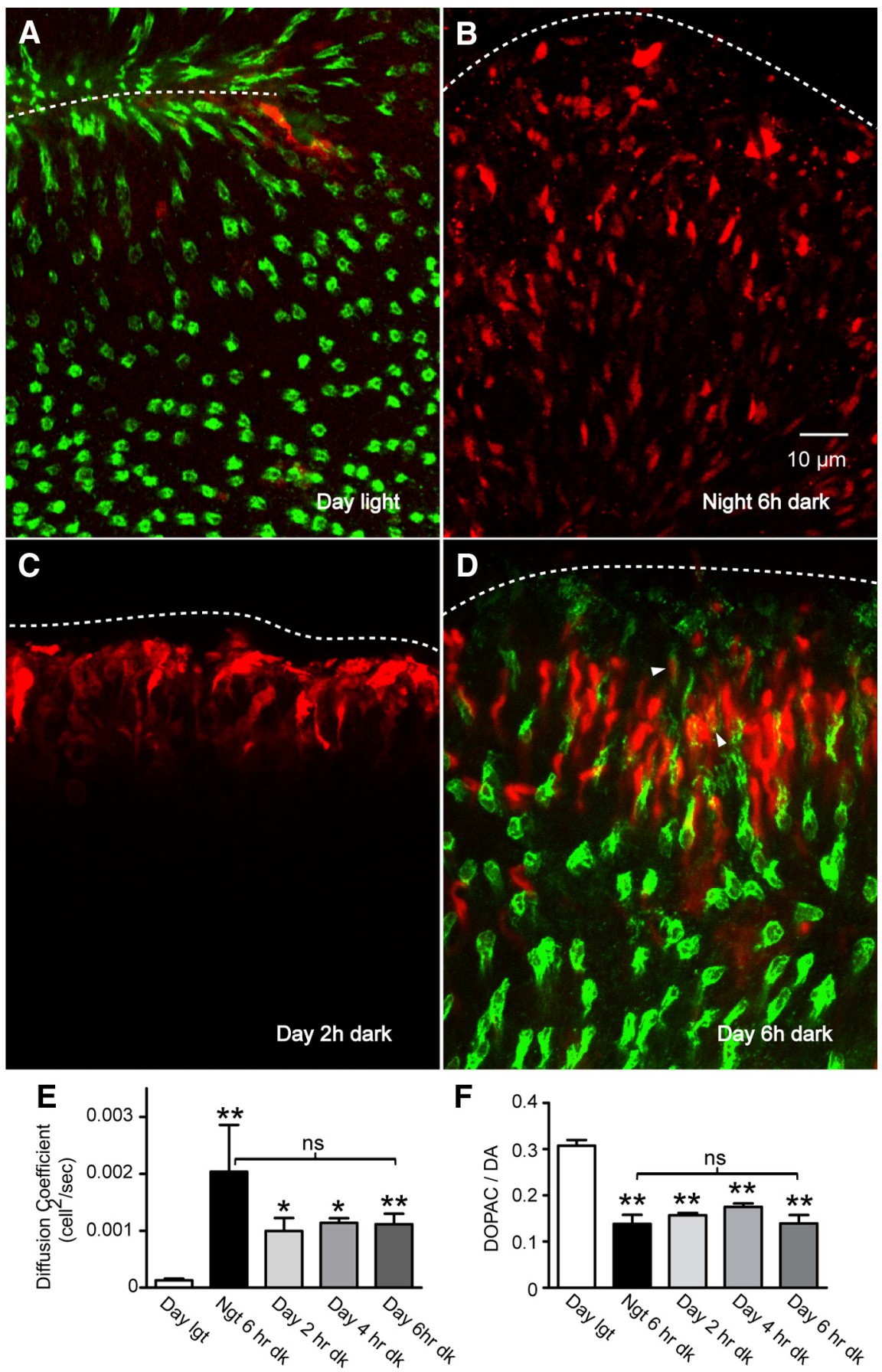

Figure 1. Photoreceptor coupling and dopamine release in light- and dark-adapted mouse retina in daytime and at night. Cut loading was conducted in mouse retina using Neurobiotin (red; $A-D$ ) followed by postfixation labeling of cones with PNA (green; $A, D$ ). Images show flat-mounted retina at the plane of the photoreceptor inner segments. Under light exposure in the daytime $(A)$, tracer diffusion was limited to the cut edge (dashed line). The majority of Neurobiotin-loaded cells were not colocalized with PNA. In the nighttime $6 \mathrm{~h}$ dark-adapted retina $(\boldsymbol{B})$, Neurobiotin tracer diffusion was much more extensive among the photoreceptor matrix. Daytime photoreceptor coupling was increased by dark adaptation for $2 \mathrm{~h}(\boldsymbol{C}), 4 \mathrm{~h}$, and $6 \mathrm{~h}(\boldsymbol{D})$, with a small fraction of cones among the coupled cells (green PNA label in D). $\boldsymbol{E}$, Summary of tracer coupling data for day; night; and 2, 4, and 6 h dark adaptation in the daytime ( $n=5-11$ per condition). $\boldsymbol{F}$, HPLC analysis of dopamine and DOPAC in whole eyes from animals collected under the same conditions as for tracer coupling measurements $\left(n=4-6\right.$ per condition). Data in $\boldsymbol{E}$ and $\boldsymbol{F}$ are mean \pm SEM; ${ }^{*} p<0.05$; ${ }^{* *} p<0.01$; ns not significant. $\boldsymbol{A}$ and $\boldsymbol{D}$ are projections comprising $4 \mu \mathrm{m}$ focal depth; $\boldsymbol{B}$ and $\boldsymbol{C}$ are projections comprising $0.9 \mu \mathrm{m}$ focal depth.

tor network was $7 \pm 0.7 \%$ (mean \pm SEM, $n=5$ ) in the daytime $6 \mathrm{~h}$ dark-adapted mouse retina. This is about twice the expected amount based on the abundance of cones in C57BL/6 mouse retina (Jeon et al., 1998), suggesting that there is some preference for cones in loading or tracer diffusion. This could simply reflect 
the larger size of cone pedicles and a proportionally increased probability of being damaged by the cut, but may also reflect isolation of some rods in the network, preventing them from acquiring tracer.

Tracer diffusion was quantified by fitting Neurobiotin label intensity in individual photoreceptors arrayed perpendicular to the cut edge to a compartmental diffusion model (Mills and Massey, 1998; Li et al., 2009). The increase in calculated Neurobiotin diffusion coefficient over the daytime, light-adapted condition was significant in each dark-adapted condition (Fig. 1E), with $6 \mathrm{~h}$ dark adaptation increasing coupling close to the extent seen in dark-adapted retina at night (one-way ANOVA, $p=$ 0.0003; followed by Bonferroni's multiple-comparison tests; $n=$ $5-11 /$ condition).

Since dopamine is considered a primary factor controlling photoreceptor coupling and dopamine release is controlled by light/dark adaptation, we examined dopamine release under each lighting condition by measuring the retinal DOPAC/dopamine ratio. DOPAC is the product of dopamine oxidation by monoamine oxidase, and is made from the pool of dopamine that is taken up into cells from the extracellular space. Therefore the DOPAC/dopamine ratio is a good index of dopamine turnover and release (Witkovsky, 2004). As expected, dopamine release was highest in the daytime light-adapted retina, and reduced in the nighttime dark-adapted retina (Fig. $1 F$ ). Dark adaptation in the daytime suppressed dopamine release, with $6 \mathrm{~h}$ dark adaptation resulting in about half the DOPAC/dopamine ratio as that of light-adapted retina. The reduction in dopamine secretion was significant at night and in all dark-adapted daytime conditions examined (one-way ANOVA: $p<0.001$; followed by Bonferroni's multiple-comparison tests; $n=4-6 /$ condition). These results show that dark adaptation of C57BL/6 mice in the daytime results in a state that is qualitatively similar to the nighttime state in that photoreceptor coupling is increased and dopamine release is reduced.

\section{Photoreceptor gap junctions contain connexin 36}

To study the molecular mechanisms that control photoreceptor coupling, it is necessary to identify the connexins involved. Cx36 has long been associated with photoreceptor coupling. Deletion of the Cx36 gene in mice leads to visual transmission deficits in the rod pathway consistent with loss of rod-cone coupling (Güldenagel et al., 2001; Deans et al., 2002; Völgyi et al., 2004). A longstanding controversy remains in the field regarding which photoreceptors express $\mathrm{Cx} 36$. Cx36 has been detected on cone pedicles in the mouse (Feigenspan et al., 2004). This is consistent with its localization at cone-cone gap junctions in fish, amphibian, and chicken retina (O'Brien et al., 2004; Zhang and Wu, 2004; Kihara et al., 2009; Li et al., 2009) and at rod-cone gap junctions in amphibian, fish, and primate retina (Zhang and Wu, 2004; Li et al., 2009; O'Brien et al., 2012). However, an immunoelectron microscopy study has found Cx36 only on the cone side of rod-cone gap junctions in guinea pig (Lee et al., 2003) and marker gene expression in one of the three $\mathrm{Cx} 36$ knock-out lines shows expression in the outer nuclear layer $(\mathrm{ONL})$ limited to a group of cells at the outer edge of the ONL, consistent with localization only in cones (Degen et al., 2004; Feigenspan et al., 2004). Marker gene expression in other Cx36 knock-out lines is more widespread, consistent with expression in both rods and cones (Deans et al., 2002) and Cx36 is clearly present at rod-rod gap junctions in the salamander retina (Zhang and $\mathrm{Wu}, 2004$ ), making an evolutionary argument in favor of its expression in rods in other vertebrates.
To contribute to this controversy, we performed confocal immunofluorescence experiments in mouse retina designed to localize Cx36 in the photoreceptor layer. Consistent with previous studies, the majority of $\mathrm{Cx} 36$-immunoreactive puncta (red) were present among photoreceptor terminals and in the OPL, with smaller numbers of gap junctions apparent among photoreceptor somata in the ONL (Fig. 2A-C). Outlines of both rod and cone photoreceptor terminals were visualized with antibodies either to PSD-95 (Fig. 2B, green) or syntaxin 3 (Fig. $2 A, C-H$, blue), with cones identified by labeling with a cone arrestin antibody (Fig. $2 A, C-H$, green). In Figure $2 B$, cones can also be identified by the broader and more irregular outline in PSD-95 immunostaining (Fig. 2B, white $\mathrm{x}$ ). In these experiments, much of the Cx36 labeling was found on the borders of rod spherules (small green circles in Fig. $2 B$, blue circles in $C, E-H$ ), consistent with either rod-rod or rod-cone gap junctions. Some Cx36 labeling in the OPL beneath cone terminals is presumed to belong to unidentified cone bipolar cells (Fig. $2 B-D, F, H$, arrowheads). Labeling of cones with a cone arrestin antibody revealed that many of the gap junctions among rod spherules actually represent contacts of rods onto cones (Fig. $2 C-H$, arrows; Fig. $2 D, E$, identical cone pedicles labeled with dark stars). A small number of $\mathrm{Cx} 36$ gap junctions associated with cone terminals appeared to be at contacts with telodendrial processes from neighboring cones (Fig. 2G,H, +), but none of these could be resolved unambiguously. Finally, gap junctions scattered through the ONL occasionally appeared to be associated with a cone axon, representing rod-cone contacts, but most appeared to be between somata of adjacent rods (Fig. $2 A, C$, white stars). This suggests that rod-rod gap junctions likely contain $\mathrm{Cx} 36$, though we cannot exclude the possibility that undetected cone telodendria make contacts with rods at these points.

In an EM reconstruction of mouse OPL, Tsukamoto et al. (2001) identified both rod-cone ( $\sim 57 \%$ of the total) and rodrod ( $\sim 42 \%$ of the total) gap junctions among photoreceptor terminals, axons, and somata in and adjacent to the OPL. A very small remaining fraction of gap junctions were cone-cone. Our immunostaining of $\mathrm{Cx} 36$ in the mouse retina is consistent with all of these gap junctions being composed of $\mathrm{Cx} 36$. In the subsequent experiments, we examine the changes in phosphorylation state of this heterogeneous pool of Cx36 gap junctions in the immediate proximity of the OPL. This pool appears to contain a dominant contribution from rod-cone gap junctions, but likely also contains rod-rod, cone-cone, and a small pool of bipolar cell gap junctions.

\section{Gap junction phosphorylation changes in concert with photoreceptor coupling}

Gap junction coupling is controlled by phosphorylation at two critical regulatory sites in Cx35/36, Ser110 and Ser276/293 (Ser276 in Cx35 is homologous to Ser293 in Cx36) (Ouyang et al., 2005; Patel et al., 2006; Kothmann et al., 2007; Li et al., 2009). A strong, positive correlation between $\mathrm{Cx} 35 / 36$ phosphorylation and neuronal coupling has been demonstrated in both rabbit and zebrafish retina (Kothmann et al., 2009; Li et al., 2009; Li and O'Brien, 2012). To test if mouse photoreceptors follow this pattern, we measured the phosphorylation levels of $\mathrm{Cx} 36$ in mouse OPL, where most photoreceptor gap junctions are located. Figure $3, A$ and $B$, show that in the OPL the phospho-S293 labeling was weak in the daytime light-adapted retina and strong in the nighttime dark-adapted retina. Two hour dark adaptation in the daytime led to increased phospho-S293 labeling (Fig. 3C), and the phosphorylation signal increased with dark adaptation extended 
to 4 and $6 \mathrm{~h}$ (Fig. 3D; $4 \mathrm{~h}$ not shown). Histograms of counts of individual gap junctions versus phosphorylation level, as measured by the ratio of phospho-S293/ $\mathrm{mCx} 36$, for daytime light-adapted and nighttime dark-adapted conditions revealed strongly skewed distributions (Fig. $3 E)$. It was not feasible to discriminate individual populations of gap junctions from these data. However, it was apparent that light adaptation in the daytime resulted in a leftward shift of the entire distribution, suggesting that the majority of gap junctions behaved in a similar manner. To quantitatively compare conditions, we calculated the median of the distribution for each animal in each condition. These comparisons revealed a significant increase in median phosphorylation level of nighttime darkadapted condition versus daytime light adapted (Fig. 3F, bottom). Dark adaptation in the daytime also led to a significant increase in phosphorylation over lightadapted control at $6 \mathrm{~h}$ dark adaptation (Fig. $3 F$, bottom; one-way ANOVA, $p=0.0094$; followed with Bonferroni's multiplecomparison tests; $n=6-9 /$ condition). There was no difference between $6 \mathrm{~h}$ dark adaptation in daytime and nighttime.

The phosphorylation level of Cx36 represents the median state of the gap junctions, regardless of any variation in size of the population. We also evaluated the total number of $\mathrm{Cx} 36$ plaques per unit volume and compared the $\mathrm{Cx} 36$ density among the conditions. There was no significant change in the number of $\mathrm{Cx} 36$ gap junctions among any of the conditions examined (Fig. 3F, top; one-way ANOVA, $p=0.691$ ). This suggests that changes in photoreceptor coupling were dominated by changes in gap junction phosphorylation state, without significant changes in the number of gap junctions present. We plotted phosphorylation level of $\mathrm{C} \times 36$ as a function of the diffusion coefficient data from the tracer coupling experiment. Consistent with previous studies in zebrafish (Li and O'Brien, 2012), there is a positive correlation between tracer coupling and phosphorylation in mouse photoreceptors (Fig. 4).

\section{Dopamine and adenosine receptors control Cx36 phosphorylation in an opposing manner}

In zebrafish retina, the changes in photoreceptor coupling and Cx35 phosphorylation associated with daytime and nighttime states were dependent on PKA activity (Li et al., 2009). Since dopamine suppresses AC activity by activating D4R, we hypothesized that adenosine may stimulate AC
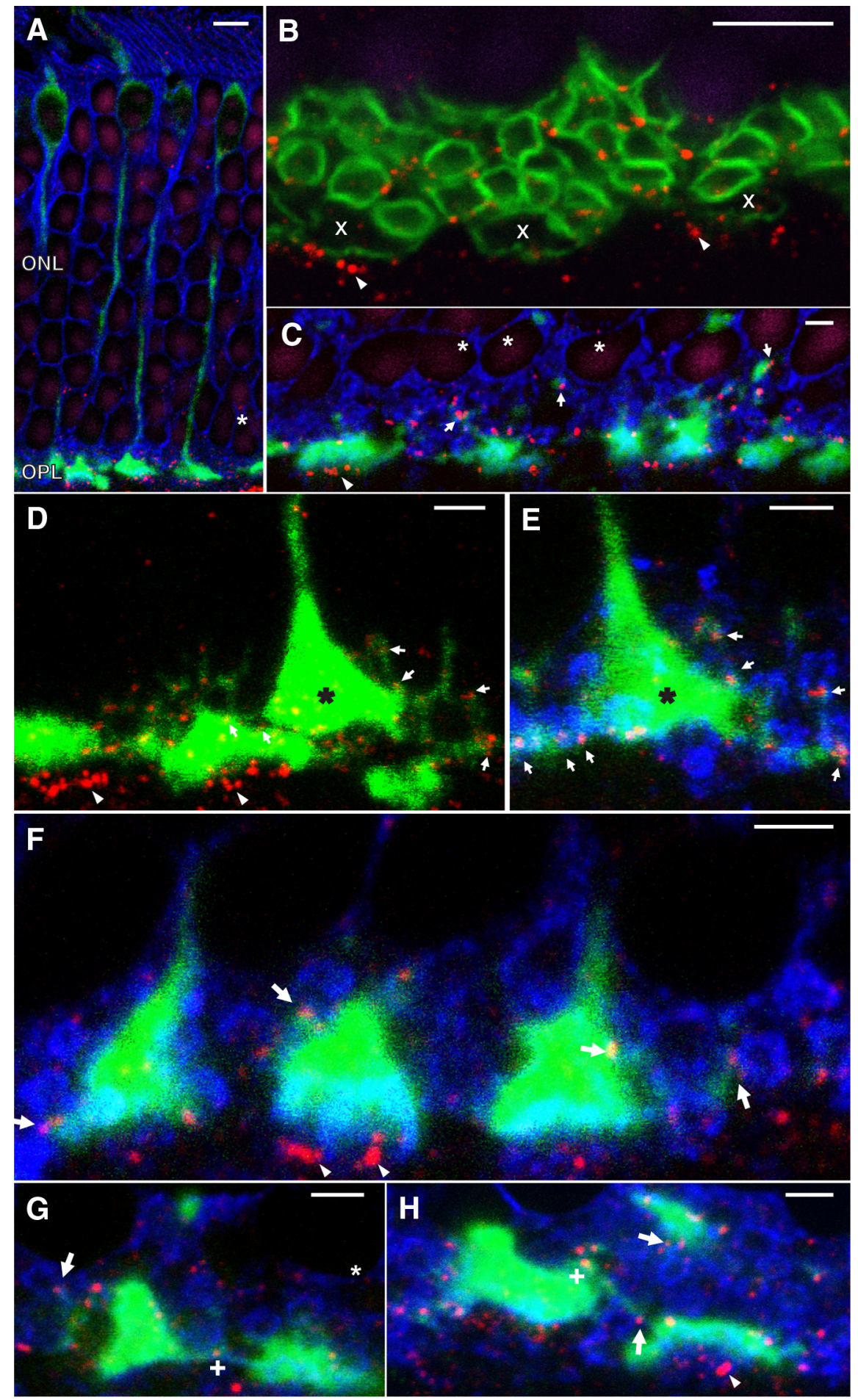

Figure 2. Immunostaining of $\mathrm{C} \times 36$ in the mouse outer retina. $A$, View of the full photoreceptor layer from outer segments (top) to OPL (bottom) labeled for syntaxin 3 (blue), cone arrestin (green), Cx36 (red), and DAPI (purple). The same color scheme is used in C $\boldsymbol{H}$. CX36 plaques were abundant in the OPL and infrequent between somata in the ONL (white star). $\boldsymbol{B}$, High-magnification view of the OPL labeled for PSD-95 (green), CX36 (red), and DAPI (purple). Numerous rod spherules appear as small circles while fewer cone pedicles are larger, dimmer, and more irregular in shape (whitex). Cx36 plaques were found associated with rod and cone membranes, as well as below cone pedicles (arrowheads). C, Cone arrestin labeling (green) revealed that many $C x 36$ plaques associated with rod membranes also contacted with cone telodendria or axons (arrows). Some small Cx36 puncta in the lower level of ONL seemed not to be associated with a cone, suggesting possible rod-rod connections (white stars). $\boldsymbol{D}$, High-magnification view of three cone pedicles showing labeling only for cone arrestin and $C \times 36$. Fine telodendria extending from the cone pedicle reach out to contact many $C \times 36$ gap junctions within the OPL.C $x 36$ gap junctions were also found by the cone axon and inside and underneath the pedicles. The cone pedicle indicated with the black star is shown again in $\boldsymbol{E}$ with syntaxin 3 labeling (blue) revealing rod terminals. Arrows show contacts between rod spherules and cone telodendria via CX36. F-G, Additional views of cones in the OPL showing rod - cone gap junctions (arrows) and potential cone-cone gap junctions ( + in Gand $\boldsymbol{H}$ ). Scale bars: (in $\boldsymbol{A}, \boldsymbol{B}) 5 \mu \mathrm{m}$; (in $\boldsymbol{C}-\boldsymbol{H}$ ) $2 \mu \mathrm{m}$. 


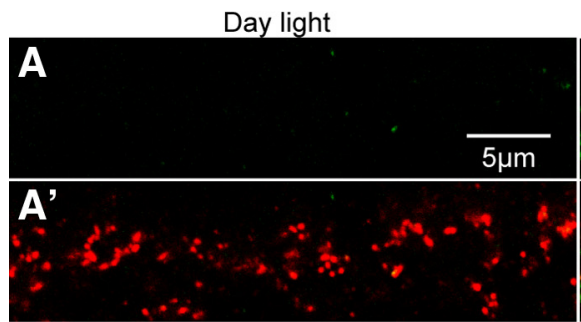

Day 2 hr dark

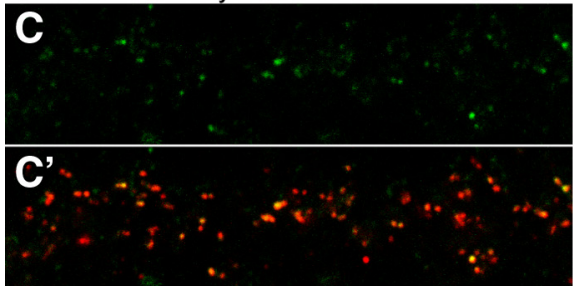

E

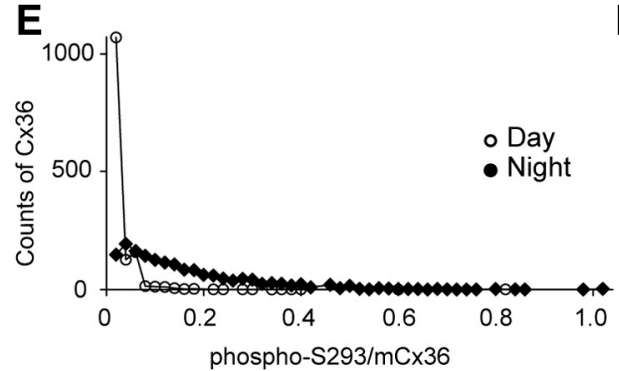

$\mathbf{F}$
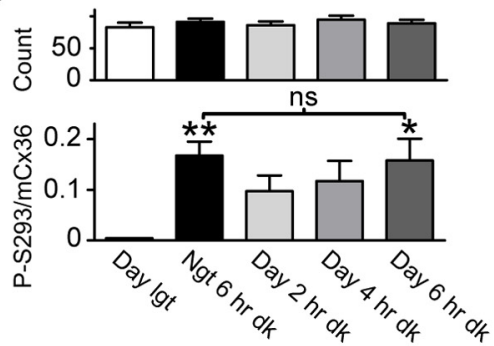

Figure 3. Phosphorylation state of $\mathrm{C} \times 36$ in the $\mathrm{OPL}$ in light- or dark-adapted mouse retina in daytime and at night. Phosphorylated Cx36 was labeled with a phospho-specific antibody against $S 293$ of $C \times 36$ (green), in reference to the total $C \times 36$ ( $\mathrm{mCx}$ 36; red). Cx36 was poorly phosphorylated in daytime light-adapted retina (A, S293-P alone; $\boldsymbol{A}^{\prime}$, phospho-S293 and mCX36 merged). In contrast, $6 \mathrm{~h}$ dark-adapted retina at night $\left(\boldsymbol{B}, \boldsymbol{B}^{\prime}\right)$ displayed strongly phosphorylated $C \times 36$. In daytime, dark adaptation for $2 \mathrm{~h}(\boldsymbol{C}$, $\left.\boldsymbol{C}^{\prime}\right)$ or $6 \mathrm{~h}\left(\boldsymbol{D}, \boldsymbol{D}^{\prime}\right)$ enhanced phosphorylation of $\mathbf{C} \times 36$. $\boldsymbol{E}$, Histogram of phosphorylation states (phospho-S293/mCX36) of individual gap junctions in nighttime dark-adapted retina (black symbols) and daytime light-adapted retina (white symbols). Data are pooled from six nighttime and six daytime animals. $\boldsymbol{F}$, Bottom, Summary of the median phosphorylation states of OPL Cx36 in daytime; nighttime; and 2, 4, and $6 \mathrm{~h}$ dark adaptation in daytime. Top, Total number of Cx36 plaques per $504 \mu \mathrm{m}^{3}$ sampling volume for the same samples is plotted. Data in $\boldsymbol{F}$ are means \pm SEM, $n=6-9$ per condition; ${ }^{*} p<0.05 ;{ }^{* *} p<0.01$; ns not significant.

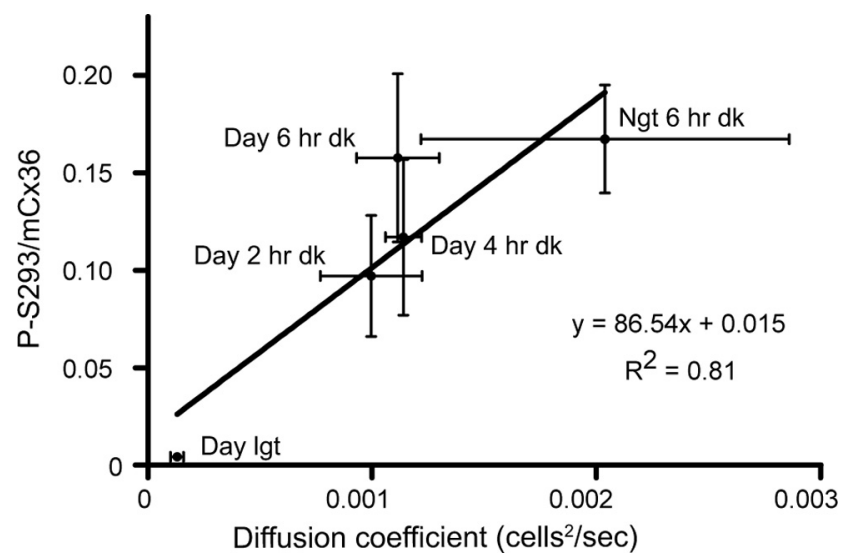

Figure 4. Cx36 phosphorylation and tracer coupling of photoreceptors are positively correlated. Based upon data shown in Figures 1 and 3, the relationship between phospho-S293/ $m C \times 36$ ratio and diffusion coefficient during cut loading under comparable conditions was analyzed. The linear regression with $R^{2}=0.81$ suggested a fairly strong, positive correlation between phosphorylation level of $\mathrm{C} \times 36$ and photoreceptor coupling. Data are means $\pm \mathrm{SEM}$.

activity through A2aR. Activation of A2aR should increase cAMP level, activate PKA, and enhance Cx36 phosphorylation and photoreceptor coupling. We used an isolated mouse eyecup preparation to test this hypothesis. Figure $5 A$ shows dose-response curves for the effects of the A2aR agonist CGS21680 and the D4R antagonist L-745870 on Cx36 phosphorylation level in daytime, under light-adapted conditions. Both inhibiting D4R and activating A2aR increased Cx36 phosphorylation level in the OPL in a dose-dependent manner (Fig. $5 A ; n=3 /$ condition). The half maximal effective concentration $\left(\mathrm{EC}_{50}\right)$ for CGS21680 was $3.2 \mu \mathrm{M}, 16$ times higher than the $\mathrm{EC}_{50}=0.2 \mu \mathrm{M}$ for elongation of isolated green sunfish cone inner segment-outer segment preparations (Rey and Burnside, 1999). The half maximal inhibitory concentration $\left(\mathrm{IC}_{50}\right)$ for $\mathrm{L}-745870$ was $0.3 \mu \mathrm{M}, \sim 34$ times higher than the $\mathrm{IC}_{50}=8.7 \mathrm{nM}$ for reversal of sulpiride suppression of ${ }^{3} \mathrm{H}$-GABA release from rat subthalamic nucleus slices (Floran et al., 2004). These differences could be due to diffusional barriers in the isolated eyecup preparation and the relatively short time course of the experiments, or they could reflect differences in the receptor properties.

If the increased phosphorylation level resulted from activation of PKA through $\mathrm{A} 2 \mathrm{aR}$ activation or D4R inhibition, we hypothesized that suppressing PKA activity concurrently would prevent the increase in phosphorylation. Indeed, as shown in Figure 5B, while 10 $\mu \mathrm{M}$ CGS21680 or $3 \mu \mathrm{M}$ L-745870 significantly increased phosphorylation, concurrently applying either drug with 10 $\mu \mathrm{M}$ PKA inhibitor Rp-8-cpt-cAMPS brought phosphorylation down to the control level (one-way ANOVA: $p<$ 0.0001; followed with Bonferroni's multiple-comparison test; $n=3-12 /$ condition).

In the reciprocal daytime, $6 \mathrm{~h}$ dark adaptation experiment (Fig. 5C), applying $75 \mathrm{nM} \mathrm{A2aR}$ antagonist CSC or $200 \mathrm{~nm} \mathrm{D4R}$ agonist PD168077, led to dephosphorylation of Cx36 in the mouse OPL. This dephosphorylation was inhibited by $10 \mu \mathrm{M}$ PKA activator Sp-8-cpt-cAMPS (Fig. 5C; one-way ANOVA: $p<$ 0.0001; followed with Bonferroni's multiple-comparison test; $n=5-8$ /condition), again suggesting that effects of D4 and A2a receptors on $\mathrm{Cx} 36$ phosphorylation in the dark are mediated by changes in PKA activity.

Provided the positive correlation between Cx36 phosphorylation and photoreceptor coupling in mouse, we expected that the high phosphorylation level induced by D4R inhibition and A2aR activation would be sufficient to increase photoreceptor coupling in the light-adapted state. Indeed, application of $3 \mu \mathrm{M} \mathrm{L}-745870$ or $10 \mu \mathrm{M}$ CGS21680 under photopic light exposure in daytime resulted in significantly increased spread of Neurobiotin through the photoreceptor matrix, to an extent similar to that observed during daytime $6 \mathrm{~h}$ dark adaptation (Fig. 6, bottom; one-way ANOVA, $p<0.0001$; followed with Bonferroni's test; $n=4-11$ / condition). Among the extensively coupled photoreceptor matrix, PNA labeling identified $\sim 5 \pm 0.5 \%$ cones in the L-745870treated retina and $\sim 8 \pm 1 \%$ in CGS-treated retina (Fig. 6, top). Neither L-745870 nor CGS21680 treatment significantly altered the proportion of coupled photoreceptor subtypes compared 


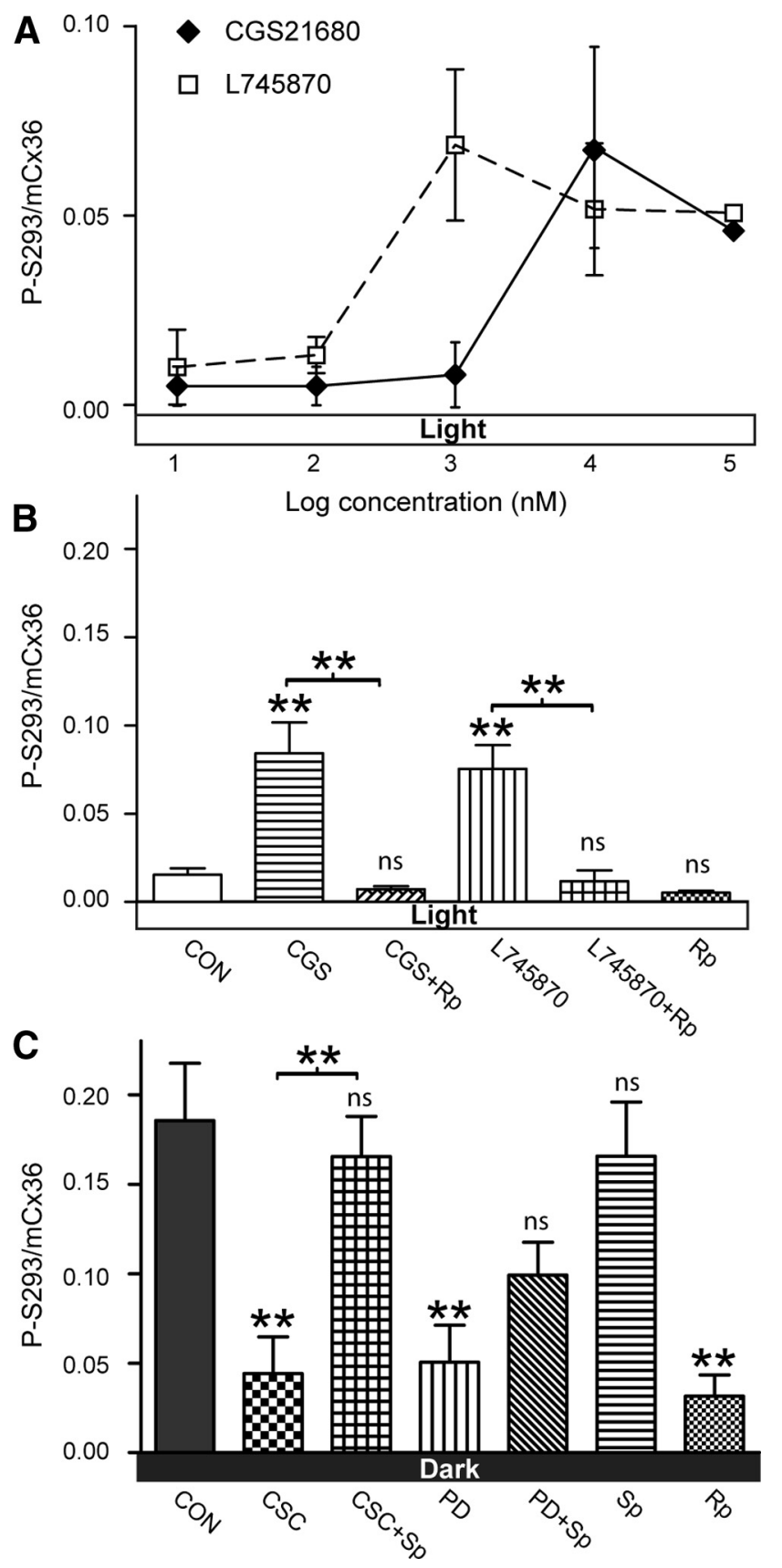

Figure 5. Adenosine A2aR and dopamine D4R regulation of photoreceptor $C \times 36$ phosphorylation in a mouse eyecup preparation. A, Dose-response curves for the A2aR agonist CGS21680 and the D4R antagonist L-745870 to phosphorylate $\mathrm{X} \times 36$ in light-adapted daytime retina. Data are means $\pm \mathrm{SEM} ; n=3$ per condition. $\boldsymbol{B}$, In daytime under photopic light exposure, activating A2aR with $10 \mu \mathrm{M}$ CGS21680 or blocking D4R with $3 \mu \mathrm{M}$ L-745870 increased Cx36 phosphorylation. These effects were blocked by concurrently applying $10 \mu \mathrm{m}$ PKA inhibitor Rp-8-CPTcAMPS. Applying only $10 \mu \mathrm{m}$ Rp showed no changes from the control group. Data are means \pm SEM; $n=3-12$ per condition. C, In daytime dark-adapted retina, inhibiting A2aR with $75 \mathrm{~nm}$ CSC or stimulating D4R with $200 \mathrm{~nm}$ PD168077 inhibited Cx36 phosphorylation. These inhibitory effects were reversed by $10 \mu \mathrm{M}$ PKA activator Sp-8-cpt-cAMPS; $10 \mu \mathrm{M}$ Sp alone showed no changes from the dark-adapted control retina, while $10 \mu \mathrm{M}$ Rp significantly reduced phosphorylation of $\mathrm{CX} 36$ in the OPL. Data are means $\pm \mathrm{SEM} ; n=5-8$ per condition. ${ }^{*} p<0.05$; ${ }^{* *} p<$ 0.01 ; ns not significant.

with daytime dark-adapted retina ( $t$ tests; $p=0.06$ and $p=0.44$ respectively; $n=4-5 /$ condition) although a reduction in proportion of cones with the D4R antagonist treatment was almost significant.

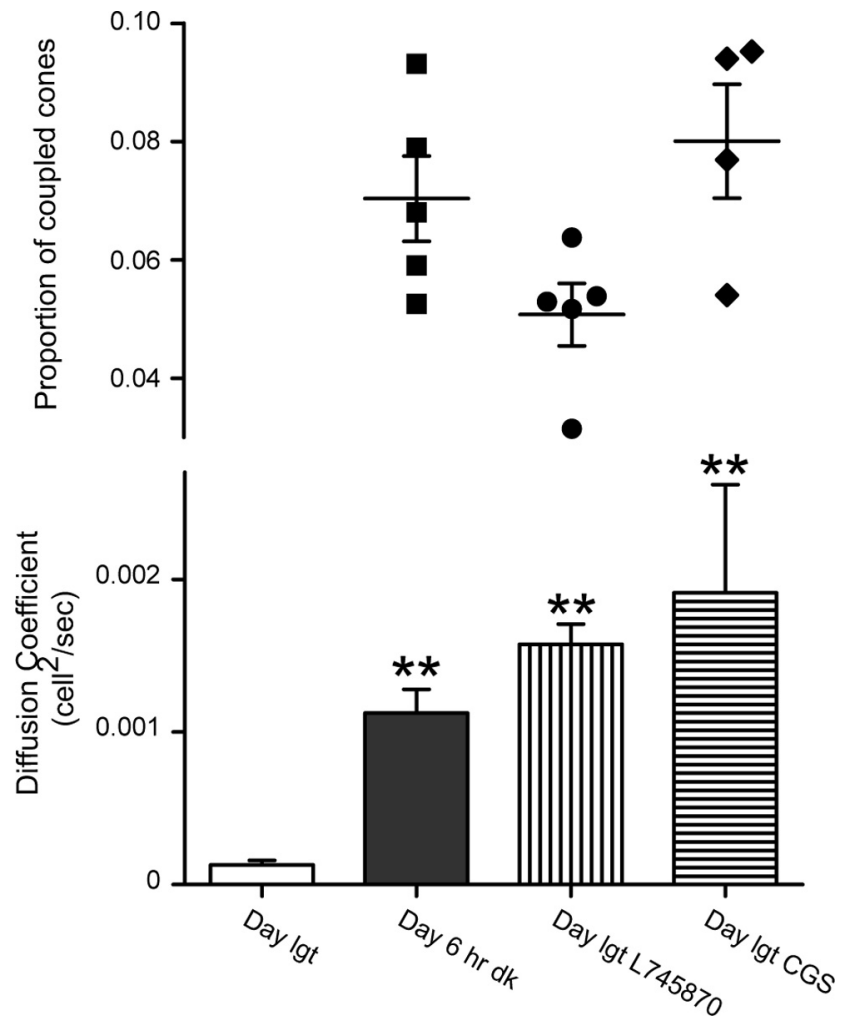

Figure 6. Effects of D4R antagonist and A2aR agonist on photoreceptor tracer coupling. Bottom, $3 \mu \mathrm{M}$ D4R antagonist L-745870 and $10 \mu \mathrm{M}$ A2aR agonist CGS21680 increased the diffusion coefficient of Neurobiotin tracer coupling in daytime light-adapted retina. Data are means \pm SEM, $n=4-11$ per condition; ${ }^{* *}$ represent significance versus daytime lightadapted condition at $p<0.01$. No difference was detected among daytime dark-adapted condition and either drug treatment in light-adapted condition (dark-adapted data are replotted from Fig. 1E). Top, Proportion of coupled cones identified by PNA staining in the same experiments (scatter plot of raw data with mean \pm SEM).

To summarize, manipulating the activity of D4R and A2aR pharmacologically, either in light or dark adaptation in daytime, is sufficient to change both the phosphorylation state of $\mathrm{Cx} 36$ and photoreceptor coupling. If these effects occur directly through $\mathrm{D} 4 \mathrm{R}$ and $\mathrm{A} 2 \mathrm{aR}$ on the photoreceptor membrane, the two G-protein-coupled receptors would provide forces antagonistic to each other to regulate AC activity, cAMP level, and PKA activity. The balance of these opposing forces provides for tight control of photoreceptor coupling.

\section{Both dopamine $\mathrm{D} 4 \mathrm{R}$ and adenosine $\mathrm{A} 2 \mathrm{aR}$ are expressed in photoreceptors in a rhythmic fashion}

Both dopamine D4 and adenosine A2a receptors have previously been localized to photoreceptors (Blazynski, 1990; Blazynski and Perez, 1991; Cohen et al., 1992; Nguyen-Legros et al., 1996, 1999; Kvanta et al., 1997; Klitten et al., 2008). Furthermore, the D4R mRNA displays a diurnal and circadian rhythm in the rodent retina (Storch et al., 2007; Bai et al., 2008; Jackson et al., 2011). If $\mathrm{D} 4 \mathrm{R}$ and $\mathrm{A} 2 \mathrm{aR}$ coordinately regulate photoreceptor coupling, their rhythmic expression may have an important influence on the balance of receptor activities that imposes this regulation. To examine the pattern and rhythmicity of D4R and A2aR expression, we conducted ISH in mouse retina sampled every $6 \mathrm{~h}$ during an L/D cycle. Figure 7 shows that the D4R transcript signal resided in the photoreceptor layer, mostly within inner segments (Fig. $7 D, D^{\prime}$, arrows) and some signal immediately adjacent to photoreceptor nuclei (Fig. $7 D^{\prime}$, arrowheads), as well as inner 


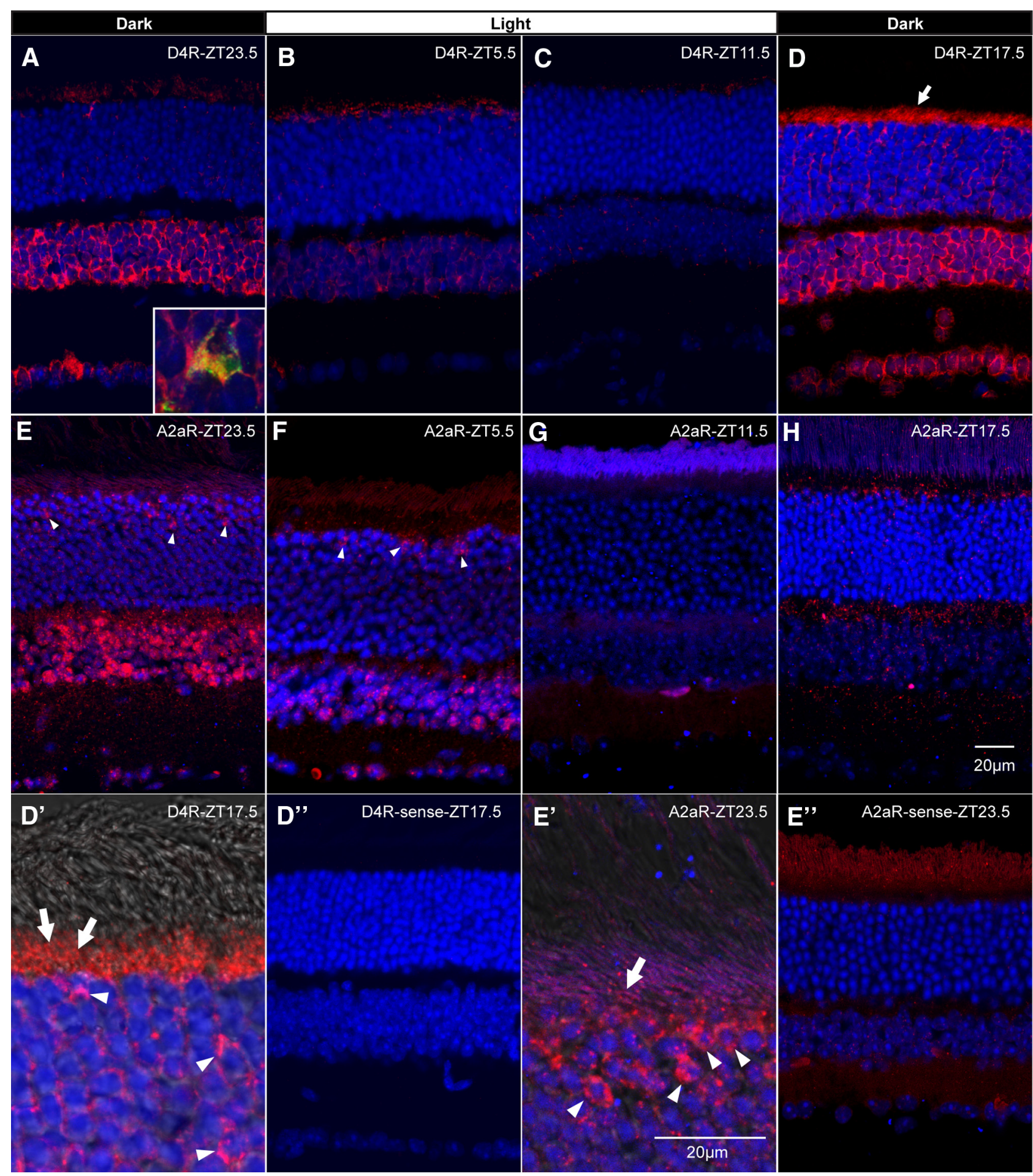

Figure 7. ISH for dopamine D4R and adenosine A2aR in mouse retina at different time points during an L/D cycle. A-D, D4R mRNA signal (red) was located in photoreceptors, most INL neurons, and ganglion cells. The sense probe resulted in negative labeling at all time points (ZT17.5 shown in $\boldsymbol{D}^{\prime \prime}$ ). Some cells in the INL showed positive tyrosine hydroxylase antibody colabeling (green; inset in $\boldsymbol{A})$. DAPI was used as nuclear counterstain (blue). The D4R transcript level was high at night $(\boldsymbol{A}, \boldsymbol{D})$ and low during the day $(\boldsymbol{B}, \boldsymbol{C})$. $\boldsymbol{E}-\boldsymbol{H}, \mathrm{A}$ similar distribution pattern was observed for the A2aR transcript (red), with signal observed in the upper ONL (arrowheads), most cells in the INL, and some ganglion cells. Sense probe labeled negatively at all time points (ZT23.5 shown in $\boldsymbol{E}^{\prime \prime}$ ). The A2aR transcript seemed high before light onset and during mid-day. Interestingly the A2aR mRNA was mainly located surrounding the somata in the upper ONL (arrowheads in $\boldsymbol{E}, \boldsymbol{E}^{\prime}$, and $\boldsymbol{F}$ ), with some mRNA signal in the inner segments (arrow in $\boldsymbol{E}^{\prime}$ ). In contrast, the majority of D4R mRNA was located in the inner segments (arrows in $D$ and $\boldsymbol{D}^{\prime}$ ), with minor signal surrounding photoreceptor somata (arrowheads in $\boldsymbol{D}^{\prime}$ ). Merged images combining bright field and fluorescence microscopy to provide image of photoreceptor outer segments $\left(\boldsymbol{D}^{\prime}, \boldsymbol{E}^{\prime}\right)$.

nuclear and ganglion cell layers (Fig. $7 A, D$ ). The sense probe resulted in no signals at all time points (Fig. $7 D^{\prime \prime}$, ZT17.5 shown). In the inner nuclear layer (INL), some neurons were colabeled with an antibody against tyrosine hydroxylase, suggesting that the dopaminergic amacrine cells express D4R (Fig. 7A, inset). The localization of D4R is consistent with previous reports by ISH in rodents (Cohen et al., 1992; Klitten et al., 2008). Moreover the $\mathrm{D} 4 \mathrm{R}$ transcript displayed a strong rhythmicity during the 
course of the day-night cycle: high in the darkness near the middle of the night and declining to a minimum near the end of the daytime. This pattern was observed in most of the D4R-positive retinal neurons and has been previously described (Storch et al., 2007; Bai et al., 2008; Jackson et al., 2011).

Interestingly, the cellular distribution pattern of $\mathrm{A} 2 \mathrm{aR}$ transcript seemed similar to that of D4R (Fig. $7 E-H$ ), with the sense probe providing negative signals (Fig. $7 E^{\prime \prime}$, ZT23.5 shown). Most INL neurons and some ganglion cells showed prominent A2aR transcript signal. The antibody against tyrosine hydroxylase failed to label dopaminergic cells in this preparation, possibly due to the prolonged TSA incubation required to detect the short cRNA probe for A2aR. A2aR mRNA transcript in photoreceptors was mainly localized to the cytoplasmic space surrounding the soma (Fig. $7 E^{\prime}$, arrowheads), in contrast to the inner segment localization of D4R mRNA hybridization (Fig. $7 D^{\prime}$, arrows). This is similar to the pattern of $\mathrm{A} 2 \mathrm{aR}$ $\mathrm{mRNA}$ localization reported in rat retina (Kvanta et al., 1997). The temporal expression of A2aR partially overlapped with D4R mRNA, with ISH labeling being highest before light onset and declining to a minimum near the end of the daytime. This expression pattern seems to occur in most A2aR-positive neurons in the retina.

\section{Adenosine receptor $2 \mathrm{a}^{-1-}$ mice have defects in the regulation of photoreceptor coupling and gap junction phosphorylation}

The pharmacological data thus far support the hypothesis that $\mathrm{A} 2 \mathrm{aR}$ and $\mathrm{D} 4 \mathrm{R}$ regulate photoreceptor coupling in an opposing manner. If the $\mathrm{A} 2 \mathrm{aR}$ provides the positive driving force, it is expected that loss of the A2aR will lead to uncoupling of photoreceptors and dephosphorylation of Cx36 due to the dominance of the D4R-dependent negative driving force. However, Neurobiotin tracer coupling was significantly higher in the daytime under light exposure in the $\mathrm{A} 2 \mathrm{a}^{-1-}$ mouse than in WT mouse retina (Fig. $8 A$; one-way ANOVA, $p=0.0003$; followed with Bonferroni's multiple-comparison test; $n=4-18$ /condition). As expected, the A2aR agonist CGS21680 (10 $\mu \mathrm{M})$ had no effect on $\mathrm{A} 2 \mathrm{a}^{-1-}$ mouse retina, while it significantly increased coupling in the photoreceptor network of WT mice. The fraction of coupled cones in $\mathrm{A} 2 \mathrm{a}^{-1-}$ retina was $6 \pm 1.1 \%$, not statistically different from the daytime dark-adapted WT retina ( $t$ test, $p=$ $0.45, n=5 /$ condition).

In keeping with the unusually high photoreceptor coupling, light-adapted $\mathrm{A} 2 \mathrm{a}^{-1-}$ retina displayed an unusually high level of Cx36 phosphorylation in the OPL (Fig. 8B). The phosphorylation level was not changed by application of the A2aR agonist CGS21680 (10 $\mu \mathrm{M})$, the D4R antagonist L-745870 (3 $\mu \mathrm{M})$, or the PKA activator Sp-8-CPT-cAMPS (10 $\mu \mathrm{M})$, although phosphory-
B

ns
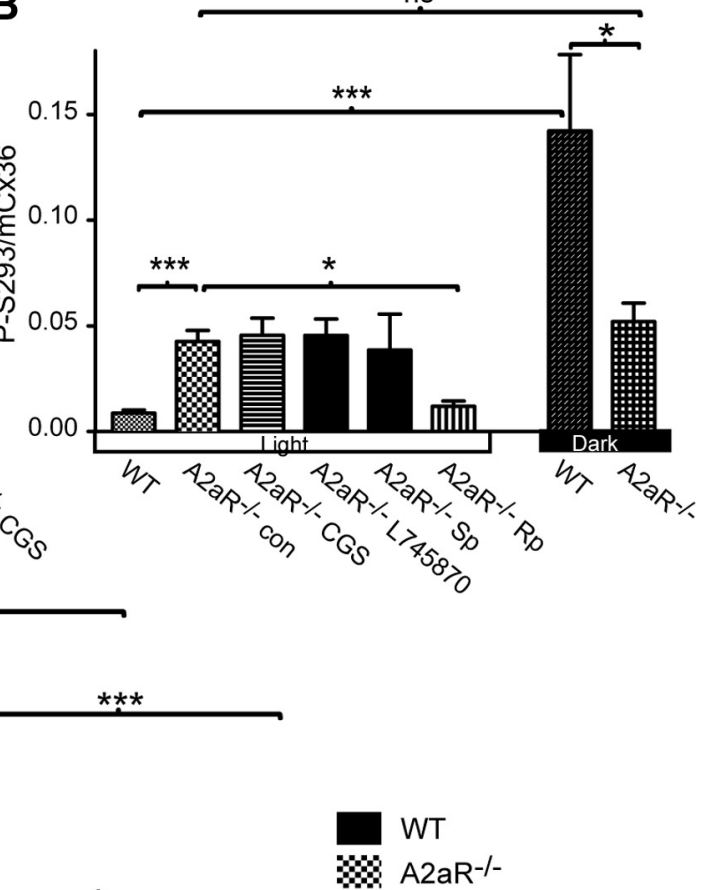

Figure 8. The $\mathrm{A} 2 \mathrm{a}^{-1-}$ mouse retina showed abnormal photoreceptor coupling and Cx36 phosphorylation. $A$, Neurobiotin tracer coupling in daytime light-adapted conditions in WT and A2a ${ }^{-1-}$ photoreceptors either in control conditions or with $10 \mu \mathrm{M}$ A2aR agonist CGS21680. Asterisks represent significance compared with the WT control condition $\left({ }^{*} p<0.05 ;{ }^{* *} p<0.01\right.$

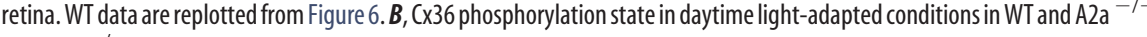
$\mu \mathrm{M}$ PKA inhibitor Rp-8-CPT-CAMPS. Compared with the light-adapted state, $6 \mathrm{~h}$ dark adaptation in the daytime in $\mathrm{A}_{2} \mathrm{a}^{-1-}$ retina 作

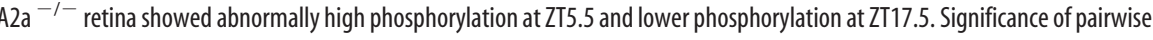
comparisons is noted above brackets identifying the pairs. Data are means \pm SEM.

lation was significantly reduced by $10 \mu \mathrm{M}$ PKA inhibitor Rp-8CPT-cAMPS (one-way ANOVA: $p<0.0001$; followed with Bonferroni's multiple-comparison test; $n=5-13 /$ condition). This suggests that PKA activity was nearly maximal and not effectively suppressed by D4R activation in the light-adapted state. $\mathrm{Cx} 36$ was significantly less phosphorylated in $\mathrm{A} 2 \mathrm{a}^{-1-}$ retina compared with WT retina following $6 \mathrm{~h}$ dark adaptation in the daytime (Student's $t$ test, $p=0.026 ; n=5-6 /$ condition), suggesting that PKA activity could not increase during dark adaptation. Finally, there was no difference in Cx36 phosphorylation level between light- and dark-adapted states at a comparable time in day in $\mathrm{A} 2 \mathrm{a}^{-1-}$ mice (Student's $t$ test, $p=0.33$ ).

We also examined the $\mathrm{Cx} 36$ phosphorylation level in the OPL of WT and A2a $\mathrm{a}^{-1-}$ mouse retina sampled every $6 \mathrm{~h}$ through an $\mathrm{L} / \mathrm{D}$ cycle. The WT retina displayed a rhythmic pattern of Cx36 phosphorylation with a minimum before light onset and a maximum near midnight (Fig. $8 C$, ZT17.5). A2 $\mathrm{a}^{-1-}$ retina displayed a significantly disrupted rhythm with a small peak during the day 


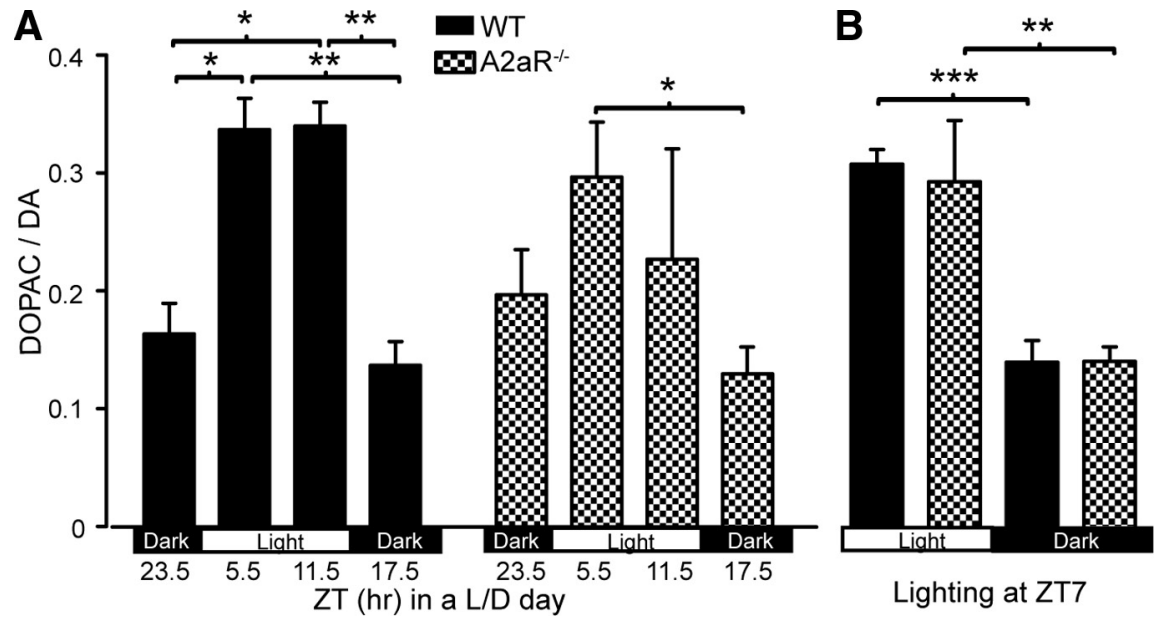

Figure 9. HPLC analysis of dopamine release in $\mathrm{A} 2 \mathrm{a}^{-1-}$ and WT mouse retina. $A$, Both $\mathrm{A} 2 \mathrm{a}^{-1-}$ and WT mouse retina displayed rhythmic dopamine release, as measured by DOPAC/dopamine during an L/D cycle. Significance of pairwise comparisons is noted above brackets identifying the pairs. There was no statistically significant difference in rhythm of dopamine release between WT and $\mathrm{A} 2 \mathrm{a}^{-1-}$ mouse retina (see text). $\boldsymbol{B}$, During daytime, $6 \mathrm{~h}$ dark adaptation significantly reduced dopamine release in both WT and $\mathrm{A} 2 \mathrm{a}^{-/-}$mouse retina. No significant difference in dopamine release was detected in either condition between the WT and the A2a ${ }^{-1-}$ mouse retina; ${ }^{*} p<0.05 ;{ }^{* *} p<0.01 ;{ }^{* * *} p<0.001$. Data are means + SEM.

(ZT5.5) and depressed phosphorylation near midnight (Fig. $8 C$; two-way ANOVA: time of the day: $p=0.012$, mouse strain: $p<$ $0.0001 ; n=3-7 /$ condition).

These results show that the $\mathrm{A} 2 \mathrm{aR}$ is essential for regulation of photoreceptor gap junction coupling and phosphorylation. The unusually high photoreceptor coupling and Cx36 phosphorylation in light-adapted retina and the lack of response to D4R antagonists suggest two possibilities: (1) the loss of the A2aR leads to a low dopamine release so that PKA activity is not suppressed by activation of the D4R or (2) the loss of the A2aR may result in downregulation of the D4R signaling cascade in photoreceptors.

To examine the first hypothesis, we measured dopamine and DOPAC in the A2 $\mathrm{a}^{-1-}$ and WT mice throughout the course of an $\mathrm{L} / \mathrm{D}$ cycle, as well as during light or dark adaptation in the daytime. A2 $\mathrm{a}^{-1-}$ mice showed a rhythm that was statistically indistinguishable from the WT mouse retina (Fig. 9A; two-way ANOVA: time of day, $p=0.0023$; mouse strain, $p=0.37 ; n=$ $3 /$ condition). The dopamine release rhythm in WT mouse retina showed elevated DOPAC/dopamine in the daytime in the presence of light and reduced DOPAC/dopamine in darkness (Bonferroni's tests: $p<0.05$, ZT23.5 vs ZT5.5, ZT23.5 vs ZT11.5; $p<$ 0.01, ZT5.5 vs ZT17.5, ZT11.5 vs ZT17.5). A2a ${ }^{-1-}$ mouse retina showed a similar rhythmicity; however, with only one pair of time points being significantly different (Bonferroni's tests: $p<$ 0.05 , ZT5.5 vs ZT17.5), suggesting that the dopamine release rhythm may be slightly dampened in the $\mathrm{A} 2 \mathrm{a}^{-1-}$ mouse. Among all conditions examined, there was no significant difference in the sum of dopamine and DOPAC (two-way ANOVA: time of the day, $p=0.07$; mouse strain, $p=0.18$ ), indicating normal dopamine synthesis in the $\mathrm{A} 2 \mathrm{a}^{-/-}$mouse.

In the $6 \mathrm{~h}$ dark adaptation paradigm, no difference in DOPAC/dopamine was observed between the WT and A2a ${ }^{-1-}$ mouse retina in either daytime, light-adapted control, or darkadapted conditions (Fig. 9B; two-way ANOVA: lighting, $p<$ 0.0001 ; mouse strain, $p=0.81 ; n=4-6 /$ condition). Dark adaptation significantly reduced DOPAC/dopamine in WT and $\mathrm{A} 2 \mathrm{a}^{-/-}$mouse retina (Student's $t$ tests: WT, $p<0.001$; A2 $\mathrm{a}^{-/-}$, $p<0.01)$. In each of these conditions, the total amount of dopamine plus DOPAC remained constant in both animal types (two- way ANOVA: lighting, $p=0.29$; mouse strain, $p=0.13$ ). These results provide evidence that the $\mathrm{A} 2 \mathrm{aR}$ had little or no influence on dopamine synthesis or the control of dopamine release. Since dopamine release in the $\mathrm{A} 2 \mathrm{a}^{-/-}$mouse was not significantly different from in the WT while regulation of photoreceptor coupling and $\mathrm{Cx} 36$ phosphorylation were significantly different (Fig. 8), and in the $\mathrm{A} 2 \mathrm{a}^{-1-}$ mouse retina dopamine release was significantly decreased by dark adaptation compared with light adaptation while $\mathrm{Cx} 36$ phosphorylation remained indistinguishable (Figs. 8, 9), it is likely that dopamine release is not a major contributor to the effects of $\mathrm{A} 2 \mathrm{aR}$ knock-out on control of photoreceptor gap junction phosphorylation.

\section{$\mathrm{D} 4 \mathrm{R}$ and $\mathrm{AC} 1$ gene expression are downregulated in the $\mathrm{A} 2 \mathrm{a}^{-1-}$ mouse retina}

To test the hypothesis that the D4R signaling cascade may be compromised in the $\mathrm{A} 2 \mathrm{a}^{-1-}$ animals we examined transcript levels of $\mathrm{D} 4 \mathrm{R}, \mathrm{A} 2 \mathrm{aR}$, and $\mathrm{AC} 1$ by real-time PCR (Fig. 10). Both A2a ${ }^{-1-}$ and WT mice showed rhythmicity in D4R gene expression (Fig. 10A; two-way ANOVA: time of the day, $p<0.0001$; mouse strain, $p=0.04 ; n=3-5 /$ condition; followed with Bonferroni's test). Consistent with the ISH data in Figure 7 and previous reports with WT mouse and rat retina (Bai et al., 2008; Klitten et al., 2008; Jackson et al., 2011), D4R transcript was higher at ZT17.5 and ZT23.5 during darkness at night compared with the levels at ZT5.5 and ZT11.5 during the day (Fig. 10A; Bonferroni's tests: $p<0.001$, ZT23.5 vs ZT5.5, ZT23.5 vs ZT11.5; ZT5.5 vs ZT17.5; $p<0.01$, ZT11.5 vs ZT17.5). The $\mathrm{D} 4 \mathrm{R}$ gene expression in $\mathrm{A} 2 \mathrm{a}^{-/-}$mouse retina peaked at ZT17.5 and remained low the rest of the day (Bonferroni's test: $p<0.01$, ZT23.5 vs ZT17.5, ZT11.5 vs ZT17.5; $p<0.001$, ZT5.5 vs ZT17.5). There was a significant reduction of D4R gene expression at ZT23.5 in the A2 $\mathrm{a}^{-/-}$mouse retina compared with the WT (Bonferroni's test: $p<0.001$ ).

Expression of A2aR was also rhythmic in the WT mouse retina. It peaked at ZT23.5 and declined at subsequent times throughout the light cycle (Fig. 10B; one-way ANOVA: $p=$ 0.008; followed with Bonferroni's test: $p<0.05$, ZT23.5 vs ZT5.5, ZT23.5 vs ZT11.5, ZT23.5 vs ZT17.5; $n=4-5$ /condition). The $\mathrm{A} 2 \mathrm{aR}$ mRNA remained undetectable in the $\mathrm{A} 2 \mathrm{a}^{-1-}$ animals at all time points ( $n=3 /$ condition).

Expression of AC1 displayed a similar pattern to that observed for A2aR in WT, peaking at ZT23.5 and declining for the rest of the day (Fig. 10C; two-way ANOVA: time of day, $p=0.048$; mouse, $p=0.05$; followed with Bonferroni's test: WT, $p<0.01$, ZT23.5 vs ZT5.5, $p<0.001$, ZT23.5 vs ZT17.5; $n=3-4$ /condition). In the $\mathrm{A} 2 \mathrm{a}^{-1-}$ mouse retina, $\mathrm{AC} 1 \mathrm{mRNA}$ was significantly downregulated at ZT23.5 compared with the WT retina (Bonferroni's tests, $p<0.01$ ), with the result that there was no significant fluctuation of AC1 mRNA through the day (Bonferroni's tests, $p=0.47)$

We further examined the expression pattern of D4R in the $\mathrm{A} 2 \mathrm{a}^{-1-}$ retina using ISH. Weak D4R mRNA signal close to background was observed in the inner segments, ONL, and INL (Fig. $10 D-G)$. Compared with the WT retina (Fig. $7 A-D)$, signal at 


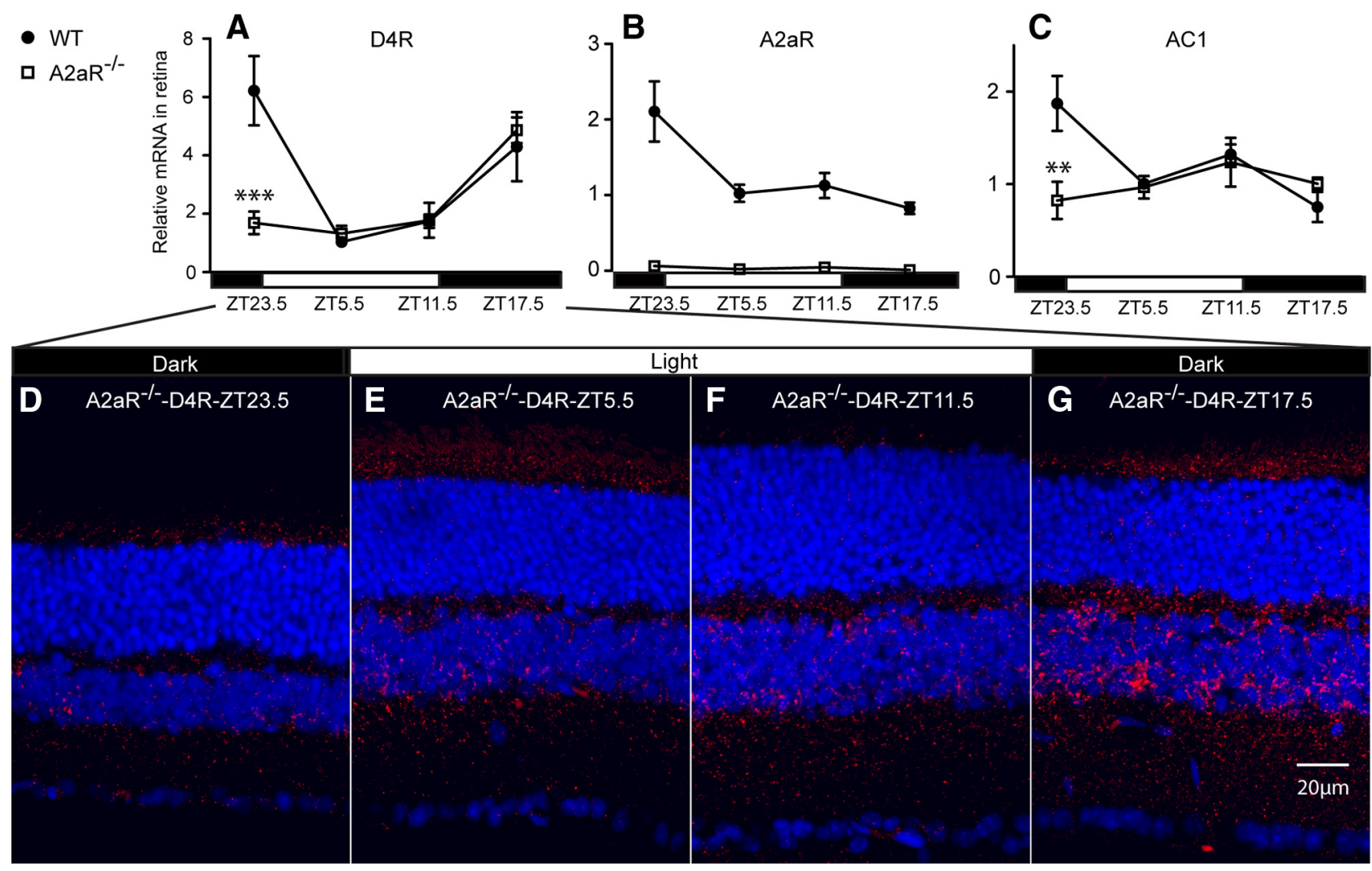

Figure 10. Gene expression of D4R, A2aR, and AC1 in the WT and A2a ${ }^{-/-}$mouse retina. A, Real-time PCR data of D4R mRNA displayed rhythmicity during an $\mathrm{L} / \mathrm{D}$ cycle in both WT and A2a ${ }^{-/-}$ mouse retinas. In WT retina it was high at ZT17.5 and ZT23.5 in the darkness during nighttime, and remained low under the daytime light. In the A2a ${ }^{-1-}$ mouse retina the D4R mRNA peaked at ZT17.5 and remained low during the rest of the day. Pairwise comparisons of relative D4R mRNA level showed a significant reduction in the A2a ${ }^{-1-}$ mouse retina at ZT23.5. B, Level of A2aRmRNA in WT mouse retina was rhythmic during an L/D cycle, peaking at ZT23.5 and remaining low at subsequent time points. A2aR transcript was negative in the A2a ${ }^{-1-}$ mouse retina. C, The AC1 mRNA in the WT mouse retina displayed its peak level at ZT23.5 and remained relatively low at other time points. No rhythmicity was observed in the A2a ${ }^{-1-}$ mouse retina, and the AC1 transcript was significantly diminished at ZT23.5 compared with WT mouse retina. Data are means $\pm S E M ;{ }^{* *} p<0.01,{ }^{* * *} p<0.001$. D-G, ISH for D4RmRNA in the A2a ${ }^{-1-}$ mouse retina. Scattered D4R signal (red) was detected in the photoreceptor and INLs, and some ganglion cells. The expression of D4R seemed relatively high at ZT17.5 (G), while remaining low at other time points during the L/D cycle $(\boldsymbol{D}-\boldsymbol{F})$. DAPI (blue) nuclear counterstain suggested that the general morphology of the A2a ${ }^{-1-}$ seemed normal.

ZT23.5 was substantially reduced in the A2a $\mathrm{a}^{-1-}$ mouse retina (Fig. 10D). The reduction in D4R mRNA signal was more dramatic than that suggested by real-time PCR, requiring different confocal parameters during imaging. The differences between ISH and real-time PCR signals may result from different sensitivity of the probes, which were nonoverlapping, or possibly to mRNA degradation. Nonetheless, these results support the hypothesis that $\mathrm{D} 4 \mathrm{R}$ expression is compromised in the $\mathrm{A} 2 \mathrm{a}^{-1-}$ mouse. The downregulated D4R and AC1 expression could explain the abnormal regulation of photoreceptor coupling and gap junction phosphorylation observed in the $\mathrm{A} 2 \mathrm{a}^{-1-}$ animals.

\section{Discussion}

Light adaptation in the retina involves a number of mechanisms that collectively allow the nearly $10 \log$ unit daily variation in environmental lighting intensity to be captured and coded into useful information by the retinal output neurons, the retinal ganglion cells. No single adaptation mechanism works throughout the range of environmental light intensity; each operates in a certain range to effect the nearly linear increment threshold relationship described by Weber's Law $(\Delta I / I=$ constant) (Dowling, 2012). Changes in photoreceptor coupling constitute one of these adaptation mechanisms. These changes are most apparent as changes in rod input into the cone pathway, or cone input into the rod pathway, via rod-cone gap junctions. This plasticity was first described in amphibian retina, in which cone input into the rod pathway increases with background illumination (Yang and $\mathrm{Wu}, 1989$ ), a change controlled by D2-like dopamine receptors (Krizaj et al., 1998). In contrast, in teleost fish and mammalian retinas, rod input into the cone pathway is suppressed by light adaptation and D2-like dopamine receptor activation (Mangel et al., 1994; Wang and Mangel, 1996; Ribelayga and Mangel, 2010; Ribelayga et al., 2002, 2008). This difference is likely related to the distinct physiological differences in retinas with large rods and a coarse cone matrix (amphibian and turtle retinas that have been studied) versus those with fine rods optimized to transmit single photon signals (Berntson et al., 2004; Sampath and Rieke, 2004). In the latter, changes in rod-cone coupling appear to occur in a relatively narrow range of light intensities in the mesopic state, the transition zone from rod-mediated scotopic vision to conemediated photopic vision (Krizaj, 2000). In this range, the suppression of rod-cone coupling has the fairly obvious benefit of preventing saturated rod signals from invading the cone pathway. Cones are also extensively coupled under the same scotopic conditions ( $\mathrm{Li}$ et al., 2009). The value of extensive cone-cone coupling in scotopic conditions is less apparent, and we have suggested that it serves the rod pathway as a mechanism to integrate and code rod responses to bright lights (Li et al., 2009) while also extending the dynamic range of rod output synapses (Attwell et al., 1987; Li et al., 2012). It should be noted that some electrophysiological studies of mammalian photoreceptors have failed 
to find any modulation of coupling (Schneeweis and Schnapf, 1999; Li and DeVries, 2004). It is not clear why this is the case, but could be a result of potent circadian control of photoreceptor coupling (Ribelayga et al., 2008) or strong $\mathrm{Ca}^{2+}$ buffering in whole-cell recording configurations (see discussion below).

Regulating rod-cone coupling within a narrow range of light adaptation requires a finely tuned synaptic mechanism. For mouse photoreceptors, we find that this mechanism depends on the phosphorylation and dephosphorylation of $\mathrm{Cx} 36$, as found previously for zebrafish photoreceptors (Li et al., 2009). Cx36 phosphorylation state correlated well with photoreceptor tracer coupling through a nearly 20 -fold dynamic range, with no change in numbers of gap junctions (Figs. 3, 4), a finding very similar to that in rabbit AII amacrine cells (Kothmann et al., 2009). In photoreceptors, phosphorylation depends on the activity of PKA, which functions as the central point of regulatory control. In this study, we have found that PKA activity is coordinately controlled by opposing actions of dopamine D4R and adenosine A2aR. These receptors sample extracellular cues that are regulated in an opposing fashion with respect to light adaptation and circadian time, providing reinforcing stimuli that will steepen the change in $\mathrm{AC}$ activity with light or dark adaptation.

D4R and A2aR canonically couple via Gi and Gs, respectively; G-proteins that have opposing effects on AC (Olah and Stiles, 1992; Chio et al., 1994). The theoretically simplest mechanism to regulate coupling would involve competition between the two G proteins to activate or inhibit the cyclase. However, the AC that has been shown to couple to $\mathrm{D} 4 \mathrm{R}$ in photoreceptors, $\mathrm{ACl}$, is a $\mathrm{Ca}^{2+}$-calmodulin stimulated AC that is quite sensitive to intracellular $\mathrm{Ca}^{2+}$ concentration but rather poorly activated by Gs (Sadana and Dessauer, 2009). Furthermore, mouse cone photoreceptor synaptic terminals have been found to undergo a large drop in intracellular $\mathrm{Ca}^{2+}$ in response to light adaptation (Johnson et al., 2007), a change that should reinforce the inhibitory effect of Gi on AC1 activity. Thus fluctuations of intracellular $\mathrm{Ca}^{2+}$ during light and dark adaptation may reinforce the effects $\mathrm{G}$ proteins to regulate coupling.

The signaling mechanism of A2aR and $\mathrm{D} 4 \mathrm{R}$ may be complicated by the potential for direct physical interaction of the two. Adenosine A2a and dopamine D2 receptors (D2R) have been found to dimerize in a variety of expression systems and neurons (Kull et al., 1999; Canals et al., 2003; Fuxe et al., 2007). This results in allosteric modulation of receptor function. For example, activation of $A 2 a R$ reduces the affinity of $D 2 R$ for dopamine and other agonists, while not affecting binding of antagonists (Ferre et al., 1991; Dasgupta et al., 1996; Ferraro et al., 2012). Interactions of $\mathrm{A} 2 \mathrm{aR}$ with $\mathrm{D} 4 \mathrm{R}$ are largely unstudied, although peptides corresponding to the receptor interaction domains of $\mathrm{A} 2 \mathrm{aR}$ and $\mathrm{D} 4 \mathrm{R}$ do form stable complexes, as do A2aR and D2R peptides (Woods, 2010). Thus it is likely that these receptors interact to modify their signaling properties.

There are further interactions of $\mathrm{A} 2 \mathrm{aR}$ and $\mathrm{D} 4 \mathrm{R}$ at the level of gene expression. This is exemplified by the downregulation of D4R transcript and loss of D4R antagonist responsiveness in the $\mathrm{A} 2 \mathrm{a}^{-1-}$ mice. It was previously noted that knock-out of the D4R resulted in reduction of AC1 expression (Jackson et al., 2009, 2011). Indeed, $\mathrm{AC} 1$ expression was reduced at its daily peak time in $\mathrm{A} 2 \mathrm{a}^{-1-}$ mice in concert with the reduction of D4R expression at its peak time, suggesting that expression of several elements of this signaling pathway are coregulated. A2aR activity has also been reported to regulate gene expression of other G-proteincoupled receptors such as adenosine A1R in chicken retina (Pereira et al., 2010) and D2R in PC-12 cells (Stonehouse et al.,
2003). What mechanisms control these compensatory changes in gene expression remain to be elucidated.

Rhythmic expression of D4R and A2aR contributes to the regulation of coupling at the transitions between night and day. The minimum Cx36 phosphorylation state occurred at ZT23.5, in anticipation of daylight and following the nocturnal peak in D4R transcript level (Fig. 8C). Since C57 BL/6 mice lack substantial circadian control of dopamine secretion (Pozdeyev et al., 2008), this minimum is likely to be driven by buildup of D4R sensing dopamine released in the dark. In similar fashion, the increase in $\mathrm{Cx} 36$ phosphorylation before nightfall may result from removal of $\mathrm{D} 4 \mathrm{R}$ receptors as a result of normal protein turnover, and consequent reduction in inhibitory signaling to AC. The slight phase lag in A2aR transcript levels may also result in a relative increase in $\mathrm{A} 2 \mathrm{aR}$ abundance compared with $\mathrm{D} 4 \mathrm{R}$ later in the day, priming the system to respond to the nocturnal increase in adenosine.

Electrical synapses are found throughout the CNS. It has become abundantly clear that plasticity is a fundamental property of electrical synapses composed of Cx36 and should be considered in all electrically connected circuits. This plasticity is driven by a number of complex signaling mechanisms that differ among cell types. Activity-dependent potentiation dependent on NMDA receptors has been observed in Mauthner cell and AII amacrine cell electrical synapses (Yang and Faber, 1991; Pereda and Faber, 1996; Kothmann et al., 2012). This mechanism depends on the activation of CaMKII and phosphorylation of the connexin (Pereda et al., 1998; Kothmann et al., 2012). The close association of Cx36 with NMDA receptors has been observed ultrastructurally in a number of other locations in the CNS as well (Rash et al., 2004), suggesting that this is a widespread mechanism. An activity-dependent depression of electrical coupling has also been observed in Mauthner cells and in thalamic reticular neurons (TRN) and requires metabotropic glutamate receptors in the TRN (Yang and Faber, 1991; Landisman and Connors, 2005; Haas et al., 2011). The molecular mechanism that effects the electrical synaptic depression has not been explored, though it likely involves activation of a phosphatase to reduce gap junction phosphorylation.

Plasticity dependent on neurohormones, such as that in the photoreceptor, is also a widespread phenomenon. Dopamine modulation of electrical coupling has been documented in many systems, but its mechanisms and outputs can vary. While activation of D4R in the photoreceptor reduces coupling by suppressing PKA activity and reducing $\mathrm{Cx} 36$ phosphorylation, activation of D1R in AII amacrine cells reduces coupling by increasing PKA activity (Hampson et al., 1992; Mills and Massey, 1995). This depends on activation of protein phosphatase $2 \mathrm{~A}$ and reduction in Cx36 phosphorylation (Kothmann et al., 2009). In contrast, dopamine increases electrical synaptic transmission at the Mauthner cell mixed synapse via D1R activation in a PKA-dependent manner (Pereda et al., 1992, 1994). The latter system functions as do photoreceptors, with coupling and presumably $\mathrm{Cx} 35$ phosphorylation directly linked to PKA activity. In each of these neural systems, an integrated signaling pathway controls the phosphorylation state of the gap junctions so that electrical synaptic connectivity can be regulated by the local environment.

\section{References}

Attwell D, Borges S, Wu SM, Wilson M (1987) Signal clipping by the rod output synapse. Nature 328:522-524. CrossRef Medline

Bai L, Zimmer S, Rickes O, Rohleder N, Holthues H, Engel L, Leube R, Spessert R (2008) Daily oscillation of gene expression in the retina is 
phase-advanced with respect to the pineal gland. Brain Res 1203:89-96. CrossRef Medline

Berntson A, Smith RG, Taylor WR (2004) Transmission of single photon signals through a binary synapse in the mammalian retina. Vis Neurosci 21:693-702. Medline

Blazynski C (1990) Discrete distributions of adenosine receptors in mammalian retina. J Neurochem 54:648-655. CrossRef Medline

Blazynski C, Perez MT (1991) Adenosine in vertebrate retina: localization, receptor characterization, and function. Cell Mol Neurobiol 11:463-484. CrossRef Medline

Bloomfield SA, Völgyi B (2009) The diverse functional roles and regulation of neuronal gap junctions in the retina. Nat Rev Neurosci 10:495-506. CrossRef Medline

Canals M, Marcellino D, Fanelli F, Ciruela F, de Benedetti P, Goldberg SR, Neve K, Fuxe K, Agnati LF, Woods AS, Ferr é S, Lluis C, Bouvier M, Franco R (2003) Adenosine A2A-dopamine D2 receptor-receptor heteromerization: qualitative and quantitative assessment by fluorescence and bioluminescence energy transfer. J Biol Chem 278:46741-46749. CrossRef Medline

Chen JF, Huang Z, Ma J, Zhu J, Moratalla R, Standaert D, Moskowitz MA, Fink JS, Schwarzschild MA (1999) A(2A) adenosine receptor deficiency attenuates brain injury induced by transient focal ischemia in mice. J Neurosci 19:9192-9200. Medline

Chio CL, Drong RF, Riley DT, Gill GS, Slightom JL, Huff RM (1994) D4 dopamine receptor-mediated signaling events determined in transfected Chinese hamster ovary cells. J Biol Chem 269:11813-11819. Medline

Choi HJ, Ribelayga CP, Mangel SC (2012) Cut-loading: a useful tool for examining the extent of gap junction tracer coupling between retinal neurons. J Vis Exp 12:pii 3180. CrossRef Medline

Cohen AI, Blazynski C (1990) Dopamine and its agonists reduce a lightsensitive pool of cyclic AMP in mouse photoreceptors. Vis Neurosci 4:43-52. CrossRef Medline

Cohen AI, Todd RD, Harmon S, O'Malley KL (1992) Photoreceptors of mouse retinas possess D4 receptors coupled to adenylate cyclase. Proc Natl Acad Sci U S A 89:12093-12097. CrossRef Medline

Dasgupta S, Ferr é S, Kull B, Hedlund PB, Finnman UB, Ahlberg S, Arenas E, Fredholm BB, Fuxe K (1996) Adenosine A2A receptors modulate the binding characteristics of dopamine D2 receptors in stably cotransfected fibroblast cells. Eur J Pharmacol 316:325-331. CrossRef Medline

Deans MR, Volgyi B, Goodenough DA, Bloomfield SA, Paul DL (2002) Connexin36 is essential for transmission of rod-mediated visual signals in the mammalian retina. Neuron 36:703-712. CrossRef Medline

Dearry A, Burnside B (1989) Light-induced dopamine release from teleost retinas acts as a light-adaptive signal to the retinal pigment epithelium. J Neurochem 53:870-878. CrossRef Medline

Degen J, Meier C, Van Der Giessen RS, Söhl G, Petrasch-Parwez E, Urschel S, Dermietzel R, Schilling K, De Zeeuw CI, Willecke K (2004) Expression pattern of lacZ reporter gene representing connexin 36 in transgenic mice. J Comp Neurol 473:511-525. CrossRef Medline

DeVries SH, Baylor DA (1995) An alternative pathway for signal flow from rod photoreceptors to ganglion cells in mammalian retina. Proc Natl Acad Sci U S A 92:10658-10662. CrossRef Medline

Dowling JE (2012) The retina: an approachable part of the brain, revised ed. Cambridge, MA: Belknap of Harvard UP.

Doyle SE, Grace MS, McIvor W, Menaker M (2002a) Circadian rhythms of dopamine in mouse retina: the role of melatonin. Vis Neurosci 19:593601. Medline

Doyle SE, McIvor WE, Menaker M (2002b) Circadian rhythmicity in dopamine content of mammalian retina: role of the photoreceptors. J Neurochem 83:211-219. CrossRef Medline

Dubocovich ML (1983) Melatonin is a potent modulator of dopamine release in the retina. Nature 306:782-784. CrossRef Medline

Dubocovich ML, Takahashi JS (1987) Use of 2-[125I]iodomelatonin to characterize melatonin binding sites in chicken retina. Proc Natl Acad Sci U S A 84:3916-3920. CrossRef Medline

Feigenspan A, Janssen-Bienhold U, Hormuzdi S, Monyer H, Degen J, Söhl G, Willecke K, Ammermüller J, Weiler R (2004) Expression of connexin36 in cone pedicles and OFF-cone bipolar cells of the mouse retina. J Neurosci 24:3325-3334. CrossRef Medline

Ferraro L, Beggiato S, Tomasini MC, Fuxe K, Antonelli T, Tanganelli S (2012) $\mathrm{A}(2 \mathrm{~A}) / \mathrm{D}(2)$ receptor heteromerization in a model of Parkinson's disease. Focus on striatal aminoacidergic signaling. Brain Res 1476:96107. CrossRef Medline

Ferre S, von Euler G, Johansson B, Fredholm BB, Fuxe K (1991) Stimulation of high-affinity adenosine A2 receptors decreases the affinity of dopamine D2 receptors in rat striatal membranes. Proc Natl Acad Sci U S A 88: 7238-7241. CrossRef Medline

Floran B, Floran L, Erlij D, Aceves J (2004) Dopamine D4 receptors inhibit depolarization-induced $[3 \mathrm{H}] \mathrm{GABA}$ release in the rat subthalamic nucleus. Eur J Pharmacol 498:97-102. CrossRef Medline

Friedman Z, Hackett SF, Linden J, Campochiaro PA (1989) Human retinal pigment epithelial cells in culture possess A2-adenosine receptors. Brain Res 492:29-35. CrossRef Medline

Fujisawa H, Morioka H, Watanabe K, Nakamura H (1976) A decay of gap junctions in association with cell differentiation of neural retina in chick embryonic development. J Cell Sci 22:585-596. Medline

Fuxe K, Ferr é S, Genedani S, Franco R, Agnati LF (2007) Adenosine receptor-dopamine receptor interactions in the basal ganglia and their relevance for brain function. Physiol Behav 92:210-217. CrossRef Medline

Güldenagel M, Ammermüller J, Feigenspan A, Teubner B, Degen J, Söhl G, Willecke K, Weiler R (2001) Visual transmission deficits in mice with targeted disruption of the gap junction gene connexin36. J Neurosci 21: 6036-6044. Medline

Haas JS, Zavala B, Landisman CE (2011) Activity-dependent long-term depression of electrical synapses. Science 334:389-393. CrossRef Medline

Hampson EC, Vaney DI, Weiler R (1992) Dopaminergic modulation of gap junction permeability between amacrine cells in mammalian retina. J Neurosci 12:4911-4922. Medline

Hansen KA, Torborg CL, Elstrott J, Feller MB (2005) Expression and function of the neuronal gap junction protein connexin 36 in developing mammalian retina. J Comp Neurol 493:309-320. CrossRef Medline

Iuvone PM, Galli CL, Garrison-Gund CK, Neff NH (1978) Light stimulates tyrosine hydroxylase activity and dopamine synthesis in retinal amacrine neurons. Science 202:901-902. CrossRef Medline

Jackson CR, Chaurasia SS, Zhou H, Haque R, Storm DR, Iuvone PM (2009) Essential roles of dopamine D4 receptors and the type 1 adenylyl cyclase in photic control of cyclic AMP in photoreceptor cells. J Neurochem 109: 148-157. CrossRef Medline

Jackson CR, Chaurasia SS, Hwang CK, Iuvone PM (2011) Dopamine D receptor activation controls circadian timing of the adenylyl cyclase 1/cyclic AMP signaling system in mouse retina. Eur J Neurosci 34:57-64. CrossRef Medline

Jeon CJ, Strettoi E, Masland RH (1998) The major cell populations of the mouse retina. J Neurosci 18:8936-8946. Medline

Johnson JE Jr, Perkins GA, Giddabasappa A, Chaney S, Xiao W, White AD, Brown JM, Waggoner J, Ellisman MH, Fox DA (2007) Spatiotemporal regulation of ATP and Ca2 + dynamics in vertebrate rod and cone ribbon synapses. Mol Vis 13:887-919. Medline

Kihara AH, Paschon V, Cardoso CM, Higa GS, Castro LM, Hamassaki DE, Britto LR (2009) Connexin36, an essential element in the rod pathway, is highly expressed in the essentially rodless retina of Gallus gallus. J Comp Neurol 512:651-663. CrossRef Medline

Klitten LL, Rath MF, Coon SL, Kim JS, Klein DC, Møller M (2008) Localization and regulation of dopamine receptor D4 expression in the adult and developing rat retina. Exp Eye Res 87:471-477. CrossRef Medline

Kothmann WW, Li X, Burr GS, O’Brien J (2007) Connexin 35/36 is phosphorylated at regulatory sites in the retina. Vis Neurosci 24:363-375. Medline

Kothmann WW, Massey SC, O’Brien J (2009) Dopamine-stimulated dephosphorylation of connexin 36 mediates AII amacrine cell uncoupling. J Neurosci 29:14903-14911. CrossRef Medline

Kothmann WW, Trexler EB, Whitaker CM, Li W, Massey SC, O’Brien J (2012) Nonsynaptic NMDA Receptors Mediate Activity-Dependent Plasticity of Gap Junctional Coupling in the AII Amacrine Cell Network. J Neurosci 32:6747-6759. CrossRef Medline

Kramer SG (1971) Dopamine: a retinal neurotransmitter. I. Retinal uptake, storage, and light-stimulated release of $\mathrm{H} 3$-dopamine in vivo. Invest Ophthalmol 10:438-452. Medline

Krizaj D (2000) Mesopic state: cellular mechanisms involved in pre- and post-synaptic mixing of rod and cone signals. Microsc Res Tech 50:347359. CrossRef Medline

Krizaj D, Gábriel R, Owen WG, Witkovsky P (1998) Dopamine D2 
receptor-mediated modulation of rod-cone coupling in the Xenopus retina. J Comp Neurol 398:529-538. CrossRef Medline

Kull B, Ferr é S, Arslan G, Svenningsson P, Fuxe K, Owman C, Fredholm BB (1999) Reciprocal interactions between adenosine A2A and dopamine D2 receptors in Chinese hamster ovary cells cotransfected with the two receptors. Biochem Pharmacol 58:1035-1045. CrossRef Medline

Kvanta A, Seregard S, Sejersen S, Kull B, Fredholm BB (1997) Localization of adenosine receptor messenger RNAs in the rat eye. Exp Eye Res 65:595602. CrossRef Medline

Lamb TD, Simon EJ (1976) The relation between intercellular coupling and electrical noise in turtle photoreceptors. J Physiol 263:257-286. Medline

Landisman CE, Connors BW (2005) Long-term modulation of electrical synapses in the mammalian thalamus. Science 310:1809-1813. CrossRef Medline

Lebedev DS, Byzov AL, Govardovskii VI (1998) Photoreceptor coupling and boundary detection. Vision Res 38:3161-3169. CrossRef Medline

Lee EJ, Han JW, Kim HJ, Kim IB, Lee MY, Oh SJ, Chung JW, Chun MH (2003) The immunocytochemical localization of connexin 36 at rod and cone gap junctions in the guinea pig retina. Eur J Neurosci 18:2925-2934. CrossRef Medline

Li H, O'Brien J (2012) Regulation of gap junctional coupling in photoreceptors. In: Photoreceptors: physiology, types and abnormalities (Akutagawa E, Ozaki K, eds). Hauppauge, NY: Nova Science.

Li H, Chuang AZ, O'Brien J (2009) Photoreceptor coupling is controlled by connexin 35 phosphorylation in zebrafish retina. J Neurosci 29: 15178-15186. CrossRef Medline

Li PH, Verweij J, Long JH, Schnapf JL (2012) Gap-junctional coupling of mammalian rod photoreceptors and its effect on visual detection. J Neurosci 32:3552-3562. CrossRef Medline

Li W, DeVries SH (2004) Separate blue and green cone networks in the mammalian retina. Nat Neurosci 7:751-756. CrossRef Medline

Londos C, Cooper DM, Wolff J (1980) Subclasses of external adenosine receptors. Proc Natl Acad Sci U S A 77:2551-2554. CrossRef Medline

Mangel SC, Baldridge WH, Weiler R, Dowling JE (1994) Threshold and chromatic sensitivity changes in fish cone horizontal cells following prolonged darkness. Brain Res 659:55-61. CrossRef Medline

Mills SL, Massey SC (1995) Differential properties of two gap junctional pathways made by AII amacrine cells. Nature 377:734-737. CrossRef Medline

Mills SL, Massey SC (1998) The kinetics of tracer movement through homologous gap junctions in the rabbit retina. Vis Neurosci 15:765-777. Medline

Nelson R (1977) Cat cones have rod input: a comparison of the response properties of cones and horizontal cell bodies in the retina of the cat. J Comp Neurol 172:109-135. CrossRef Medline

Nguyen-Legros J, Chanut E, Versaux-Botteri C, Simon A, Trouvin JH (1996) Dopamine inhibits melatonin synthesis in photoreceptor cells through a D2-like receptor subtype in the rat retina: biochemical and histochemical evidence. J Neurochem 67:2514-2520. Medline

Nguyen-Legros J, Versaux-Botteri C, Vernier P (1999) Dopamine receptor localization in the mammalian retina. Mol Neurobiol 19:181-204. CrossRef Medline

Nir I, Haque R, Iuvone PM (2000) Diurnal metabolism of dopamine in the mouse retina. Brain Res 870:118-125. CrossRef Medline

Nowak JZ, Kazula A, Golembiowska K (1992) Melatonin increases serotonin $\mathrm{N}$-acetyltransferase activity and decreases dopamine synthesis in light-exposed chick retina: in vivo evidence supporting melatonindopamine interaction in retina. J Neurochem 59:1499-1505. CrossRef Medline

O'Brien JJ, Chen X, Macleish PR, O'Brien J, Massey SC (2012) Photoreceptor coupling mediated by connexin 36 in the primate retina. J Neurosci 32:4675-4687. CrossRef Medline

O’Brien J, Nguyen HB, Mills SL (2004) Cone photoreceptors in bass retina use two connexins to mediate electrical coupling. J Neurosci 24:56325642. CrossRef Medline

Olah ME, Stiles GL (1992) Adenosine receptors. Annu Rev Physiol 54:211225. CrossRef Medline

Ouyang X, Winbow VM, Patel LS, Burr GS, Mitchell CK, O’Brien J (2005) Protein kinase A mediates regulation of gap junctions containing connexin35 through a complex pathway. Brain Res Mol Brain Res 135:1-11. Medline

Patel LS, Mitchell CK, Dubinsky WP, O’Brien J (2006) Regulation of gap junction coupling through the neuronal connexin Cx35 by nitric oxide and cGMP. Cell Commun Adhes 13:41-54. CrossRef Medline

Pereda AE, Faber DS (1996) Activity-dependent short-term enhancement of intercellular coupling. J Neurosci 16:983-992. Medline

Pereda AE, Nairn AC, Wolszon LR, Faber DS (1994) Postsynaptic modulation of synaptic efficacy at mixed synapses on the Mauthner cell. J Neurosci 14:3704-3712. Medline

Pereda AE, Bell TD, Chang BH, Czernik AJ, Nairn AC, Soderling TR, Faber DS (1998) Ca2+/calmodulin-dependent kinase II mediates simultaneous enhancement of gap-junctional conductance and glutamatergic transmission. Proc Natl Acad Sci U S A 95:13272-13277. CrossRef Medline

Pereda A, Triller A, Korn H, Faber DS (1992) Dopamine enhances both electrotonic coupling and chemical excitatory postsynaptic potentials at mixed synapses. Proc Natl Acad Sci U S A 89:12088-12092. CrossRef Medline

Pereira MR, Hang VR, Vardiero E, de Mello FG, Paes-de-Carvalho R (2010) Modulation of A1 adenosine receptor expression by cell aggregation and long-term activation of A2a receptors in cultures of avian retinal cells: involvement of the cyclic AMP/PKA pathway. J Neurochem 113:661-673. CrossRef Medline

Pierce ME, Besharse JC (1985) Circadian regulation of retinomotor movements. I. Interaction of melatonin and dopamine in the control of cone length. J Gen Physiol 86:671-689. CrossRef Medline

Pozdeyev N, Tosini G, Li L, Ali F, Rozov S, Lee RH, Iuvone PM (2008) Dopamine modulates diurnal and circadian rhythms of protein phosphorylation in photoreceptor cells of mouse retina. Eur J Neurosci 27: 2691-2700. CrossRef Medline

Rash JE, Pereda A, Kamasawa N, Furman CS, Yasumura T, Davidson KG, Dudek FE, Olson C, Li X, Nagy JI (2004) High-resolution proteomic mapping in the vertebrate central nervous system: close proximity of connexin 35 to NMDA glutamate receptor clusters and co-localization of connexin 36 with immunoreactivity for zonula occludens protein-1 (ZO-1). J Neurocytol 33: 131-151. CrossRef Medline

Rey HL, Burnside B (1999) Adenosine stimulates cone photoreceptor myoid elongation via an adenosine A2-like receptor. J Neurochem 72: 2345-2355. Medline

Ribelayga C, Mangel SC (2005) A circadian clock and light/dark adaptation differentially regulate adenosine in the mammalian retina. J Neurosci 25:215-222. CrossRef Medline

Ribelayga C, Mangel SC (2010) Identification of a circadian clockcontrolled neural pathway in the rabbit retina. PLoS One 5:e11020. CrossRef Medline

Ribelayga C, Wang Y, Mangel SC (2002) Dopamine mediates circadian clock regulation of rod and cone input to fish retinal horizontal cells. J Physiol 544:801-816. CrossRef Medline

Ribelayga C, Wang Y, Mangel SC (2004) A circadian clock in the fish retina regulates dopamine release via activation of melatonin receptors. J Physiol 554:467-482. Medline

Ribelayga C, Cao Y, Mangel SC (2008) The circadian clock in the retina controls rod-cone coupling. Neuron 59:790-801. CrossRef Medline

Roseboom PH, Namboodiri MA, Zimonjic DB, Popescu NC, Rodriguez IR, Gastel JA, Klein DC (1998) Natural melatonin 'knockdown' in C57BL/6J mice: rare mechanism truncates serotonin N-acetyltransferase. Brain Res Mol Brain Res 63:189-197. Medline

Sadana R, Dessauer CW (2009) Physiological roles for G protein-regulated adenylyl cyclase isoforms: insights from knockout and overexpression studies. Neurosignals 17:5-22. CrossRef Medline

Sampath AP, Rieke F (2004) Selective transmission of single photon responses by saturation at the rod-to-rod bipolar synapse. Neuron 41:431443. CrossRef Medline

Schmittgen TD, Livak KJ (2008) Analyzing real-time PCR data by the comparative C(T) method. Nat Protoc 3:1101-1108. CrossRef Medline

Schneeweis DM, Schnapf JL (1995) Photovoltage of rods and cones in the macaque retina. Science 268:1053-1056. CrossRef Medline

Schneeweis DM, Schnapf JL (1999) The photovoltage of macaque cone photoreceptors: adaptation, noise, and kinetics. J Neurosci 19:1203-1216. Medline

Stella SL Jr, Bryson EJ, Thoreson WB (2002) A2 adenosine receptors inhibit calcium influx through L-type calcium channels in rod photoreceptors of the salamander retina. J Neurophysiol 87:351-360. Medline

Stella SL Jr, Bryson EJ, Cadetti L, Thoreson WB (2003) Endogenous aden- 
osine reduces glutamatergic output from rods through activation of A2like adenosine receptors. J Neurophysiol 90:165-174. CrossRef Medline

Stonehouse AH, Adachi M, Walcott EC, Jones FS (2003) Caffeine regulates neuronal expression of the dopamine 2 receptor gene. Mol Pharmacol 64:1463-1473. CrossRef Medline

Storch KF, Paz C, Signorovitch J, Raviola E, Pawlyk B, Li T, Weitz CJ (2007) Intrinsic circadian clock of the mammalian retina: importance for retinal processing of visual information. Cell 130:730-741. CrossRef Medline

Streitová D, Sefc L, Savvulidi F, Pospísil M, Holá J, Hofer M (2010) Adenosine $\mathrm{A}(1), \mathrm{A}(2 \mathrm{a}), \mathrm{A}(2 \mathrm{~b})$, and $\mathrm{A}(3)$ receptors in hematopoiesis. 1. Expression of receptor mRNA in four mouse hematopoietic precursor cells. Physiol Res 59:133-137. Medline

Trümpler J, Dedek K, Schubert T, de Sevilla Müller LP, Seeliger M, Humphries P, Biel M, Weiler R (2008) Rod and cone contributions to horizontal cell light responses in the mouse retina. J Neurosci 28:68186825. CrossRef Medline

Tsukamoto Y, Morigiwa K, Ueda M, Sterling P (2001) Microcircuits for night vision in mouse retina. J Neurosci 21:8616-8623. Medline

Völgyi B, Deans MR, Paul DL, Bloomfield SA (2004) Convergence and segregation of the multiple rod pathways in mammalian retina. J Neurosci 24:11182-11192. CrossRef Medline
Wang Y, Mangel SC (1996) A circadian clock regulates rod and cone input to fish retinal cone horizontal cells. Proc Natl Acad Sci U S A 93:4655-4660. CrossRef Medline

Weiler R, Kohler K, Kirsch M, Wagner HJ (1988) Glutamate and dopamine modulate synaptic plasticity in horizontal cell dendrites of fish retina. Neurosci Lett 87:205-209. CrossRef Medline

Witkovsky P (2004) Dopamine and retinal function. Doc Ophthalmol 108: 17-40. CrossRef Medline

Woods AS (2010) The dopamine D(4) receptor, the ultimate disordered protein. J Recept Signal Transduct Res 30:331-336. CrossRef Medline

Yang XD, Faber DS (1991) Initial synaptic efficacy influences induction and expression of long-term changes in transmission. Proc Natl Acad Sci U S A 88:4299-4303. CrossRef Medline

Yang XL, Wu SM (1989) Modulation of rod-cone coupling by light. Science 244:352-354. CrossRef Medline

Zhang J, Wu SM (2004) Connexin35/36 gap junction proteins are expressed in photoreceptors of the tiger salamander retina. J Comp Neurol 470:112. CrossRef Medline

Zimmerman AL, Rose B (1985) Permeability properties of cell-to-cell channels: kinetics of fluorescent tracer diffusion through a cell junction. J Membr Biol 84:269-283. CrossRef Medline 